\title{
PARALELIZM WARTOŚCI IDEOWYCH, ARTYSTYCZNYCH I PRZESTRZENNYCH EREMU OO. KAMEDULÓW NA BIE- LANACH W KRAKOWIE Z PUSTELNIĄ KARMELITÓW BO- SYCH W CZERNEJ DO KOŃCA XVIII WIEKU
}

\author{
FUNDACJA EREMU OO. KAMEDUŁÓW NA BIELANACH \\ I EREMU KARMELITÓW BOSYCH W CZERNEJ
}

Przedmiotem tego wystapienia jest koicydencja czasowa, historyczna, geograficzna oraz paralelizm wartości ideowych i artystycznych dwóch pustelni, usytuowanych w niedalekiej odległości od siebie, na malowniczym terenie Jury Krakowsko-Częstochowskiej, należących do Zakonu OO. Kamedułów na Bielanach i Karmelitów Bosych w Czernej. Dokładnie 400 lat temu z inspiracji papieża Klemensa VIII Mikołaj Wolski (1549-1630), marszałek nadworny króla Zygmunta III Wazy, zaproponował w 1602 roku oo. kamedułom z eremu Montis Coronae w Italii fundację w Krakowie. Zanim o. Rudolf z Perugii podjął ostateczną decyzję, wpierw $\mathrm{z}$ woli kapituły generalnej wysłał w 1603 roku na wizję lokalną do Krakowa o. Hieronima z Perugii i dwóch towarzyszy dla wlaściwego rozpoznania warunków i wyboru najodpowiedniejszego miejsca pod erem ${ }^{1}$. Delegaci towarzyszącemu marszałkowi Wolskiemu wskazali i wybrali za jedyne pod erem miejsce wzniesienie nad Wisłą $w$ miejscowości Bielany $z$ przyległym lasem ${ }^{2}$. Miejscowość ta należała do burgrabiego krakowskiego Sebastiana Lubomirskiego, kasztelana wojnickiego. Marszałek koronny przez pośrednictwo jego małżonki Anny z Branickich Lubomirskiej wyjednał darowiznę Bielan na rzecz kamedułów. Mikołaj Wolski aktem w urzędzie grodzkim w Krakowie 22 II 1604 r na rzecz fundacji zapisał kamedułom wsie Mników i Mnikówek ${ }^{3}$, a Sebastian Lubomirski

${ }^{1}$ L. Z a rew ic z, Zakon kamedulów, jego fundacje i dziejowe wspomnienia $w$ Polsce i Litwie, Kraków 1781, s. 7-9; S. C h [ o d yń s k i ] ks., „Kameduli”, [w:] Encyklopedia kościelna..., wydana przez X. Michała Nowodworskiego, t. IX, Warszawa 1876, s. 391-392.

${ }^{2}$ L. Z a rew i c $z$, op. cit., s. 55.

${ }^{3}$ Biblioteka Czartoryskich w Krakowie, rkps 2894, dok. 48; W. Kret, Problematyka artystyczna kościola OO. Kamedulów na Bielanach pod Krakowem, „Kwartalnik Architektury i Urbanistyki", t. XII, Warszawa 1967, z. 3-4. s. 23. 
7 IV 1604 r. wieś Bielany z górą zwaną „srebrną". Po wystawieniu w kancelarii królewskiej w Krakowie 10 IV 1604 r. wspólnego dokumentu erekcyjnego ${ }^{5}$ z dołączonym przyzwoleniem i zaproszeniem biskupa krakowskiego Bernarda Maciejowskiego (21 VII 1603) ${ }^{6}$ i króla Zygmunta III Wazy (z 8 IV 1604) ${ }^{7}$ przesłano dokument do przełożonego generalnego w Eremie Góry Koronnej w Italii. Na tej podstawie w maju 1605 roku Paweł Henik - kawaler jerozolimski i przyjaciel Mikołaja Wolskiego sprowadził z Włoch do Krakowa 5-ciu kamedułów z przełożonym Hieronimem z Perugii ${ }^{8}$. Na czas budowy 20 domków pustelni (eremitarzy) na Bielanach fundator tymczasowo umieścił przybyłych synów duchowych św. Romualda pod opieką ojców benedyktynów tynieckich w Budzowie ${ }^{9}$.

W tym samym czasie Klemens VIII 7 VIII 1604 r. wysłał z Rzymu trzech karmelitów bosych (o. Pawła Szymona od Jezusa i Maryi Rivarolę, o. Jana Tadeusza od św. Elizeusza Roldana, o. Wincentego od św. Franciszka Gambarta i br. Jana od Wniebowzięcia Angeli'ego) z misją apostolską i dyplomatyczną do króla perskiego Abbasa I Wielkiego w Isfahanie ${ }^{10}$. Misjonarze z powodu niebezpieczeństwa ze strony islamu obrali drogą lądową przez Austrię, Czechy, Polskę i Rosję. $Z$ listami polecającymi od Papieża do króla polskiego Zygmunta III Wazy i nuncjusza ap. Klaudiusza Rangoniego przybyli oni do Krakowa 25 VIII 1604 roku ${ }^{11}$. Zamieszkali u nuncjusza apostolskiego, który przedstawił ich królowi Zygmuntowi III, jako legatów Stolicy Apostolskiej. Przekazali mu polecające listy od Papieża, oraz złożyli wizytę królewiczowi Władysławowi i kard. Bernardowi Maciejowskiemu ${ }^{12}$. Pobyt ich w Krakowie i na terenie Polski przedłużył się z powodu wojny w Rosji o tron pomiędzy zwolennikami Borysa Godunowa i Dymitra Samozwańca. Obecność ich w Polsce zjednała im wielu sympatyków. Stąd przedstawiciele władzy duchowej: nuncjusz apostolski Klaudiusz Rangoni, bp krakowski kard. Bernard Maciejowski i metropolita unicki Hypacy Pociej, zwrócili się do generała zakonu w Rzymie i do Stolicy Apostolskiej o fundację klasztoru karme-

${ }^{4}$ P. T. Lug a n o, La Congregazione Camaldolense degli Eremitici di Montecorona, Frascati MCMVIII (1908), s. 333. Według tradycji Mikołaj Wolski z wdzięczności za odstapienie Bielan na rzecz fundacji kamedułów ofiarował w zamian Lubomirskiemu wielką ilość naczyń srebrnych stołowych, z tego powodu górę tę nazwano „srebrną" - Mons argenteus. Zob. M. B a li ń sk i i T. L i p iń s k i, Starożytna Polska pod względem historycznym, jeograficznym i statystycznym, t. II, Kraków 1844, s. 68.

${ }^{5}$ Annales Camaldunenses Ordinis sancti Benedicti, ... opera et studio D. Johannis Benedicti Mittarelli et D. Anzelmi Costadoni abbatum camaldunensium, t. IX, Venetiis MDCCLXXIII (1773), kol. 256.

${ }^{6}$ Tamże, s. 239.

${ }^{7}$ Tamze, s. 242.

${ }^{8}$ L. Z a rew i c z, op. cit., s. 56; P. T. Lu g a n o, op. cit., s. 334.

${ }^{9}$ A. B i a ł u c h a EC, Prolog, [w:] A. B u j a k, Tajemnica Kamedułów, Kraków 2000, s. 25.

${ }^{10}$ Florencio del Nino Jesus, A Persia, [w:] Biblioteca Carmelitano-Teresiana de Misiones, t. II, Pamlona 1929, s. 17-20; J o a n e s a J e s u M a r i a, Historia Missionum, [w:] Opera omia, t. IV, Coloniae Agrypinae 1650. s. $42-65$.

11 Tamże, s. 20-23; L. K ow a ló w k a OCD, Z naszej przeszłości misyjnej, Rzym 1975,

${ }^{12}$ Cz. Gil OCD, Karmelici bosi w Polsce 1605-1655, „Nasza Przeszłość”, t. XLVIII, Kraków 1977, s. 18. 
litów bosych w Krakowie. Po śmierci Klemensa VIII (5 III 1605) pap. Paweł V popierał tę fundację jak wynika $\mathrm{z}$ jego listów pisanych do kard. Maciejowskiego ${ }^{13}$, i do króla Zygmunta III $^{14}$. Kapituła generalna Karmelitów Bosych w Rzymie po zapoznaniu się z powyższymi prośbami w dniu 5 maja 1605 r. przyjęła fundację w Krakowie $^{15}$. Dnia 28 XI 1605 r. przybyli na fundację do Krakowa: o. Maciej od św. Franciszka (Didacus Hurtado de Mendoza), o. Jan od Najśw. Sakramentu, o. Alfons od Matki Bożej - wszyscy trzej Hiszpanie, oraz br. Jakub od św. Bartłomieja - Włoch z Neapolu ${ }^{16}$. Osiedlili się na przedmieściu Krakowa, za bramą i kościołem św. Mikołaja, w ogrodzie Jadwigi Padniewskiej - kasztelanowej oświęcimskiej, zakupionym przez bpa przemyskiego i kanclerza koronnego Macieja Pstrokońskiego dla karmelitów bosych, przybyłych z Rzymu ${ }^{17}$. Tutaj wybudowali klasztor i kościół pod wezw. Niepokalanego Poczęcia NMP (obecnie szpital św. Łazarza). W krótkim czasie założyli klasztory w: Lublinie (1610), we Lwowie (1613), Krakowie pw. SS. Michała i Józefa (1617), Poznaniu (1618), Przemyślu (1620), Wiśniczu (1621). Na Kapitule Generalnej w Rzymie 14 maja 1617 roku dla klasztorów w Polsce utworzono autonomiczna prowincję pod wezw. Ducha Świętego ${ }^{18}$. Zgodnie z przepisami konstytucji zakonu, że każda prowincja ma posiadać swój erem czyli klasztor pustelniczy ${ }^{19}$, Definitorium Generalne w Rzymie 20 VI 1620 roku upoważniło o prowincjała Michała od Zwiastowania (Michael a Vidarte) do założenia eremu dla polskiej prowincji ${ }^{20}$. Fundatorką eremu karmelitów bosych w Czernej była Agnieszka z Tęczyńskich Firlejowa (1578-1644), wojewodzina krakowska, wdowa po Mikolaju Firleju z Dąbrowicy, wojewodzie krakowskim. Aktem fundacyjnym w Rogowie 10 maja 1631 roku erygowała klasztor pustelniczy pod wezw. Św. Eliasza, zapisując klasztorowi wsie: Paczóltowice, Siedlec, Żbik, młyn chechelski i części w Żarach, na zbudowanie klasztoru i stałe utrzymanie pustelników (czyli 600 ha lasu i 600 ha gruntu

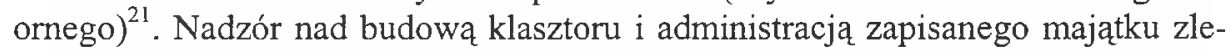

${ }^{13}$ Biblioteka Polskiej Akademii Nauk w Kórniku, rkps 344, Akta różnych czasów panowania Zygmunta III, k. 8-9; B. J. W a n a t OCD, Zakon Karmelitów Bosych w Polsce, Klasztory karmelitów i karmelitanek bosych 1605-1975, Kraków 1979, s. 85-86.

${ }^{14}$ Tamże.

15 Archiwum Prowincji Karmelitów Bosych w Czernej (APKB), sygn. AP 7, Acta Capituli Generalis Fratrum Carmelitarum Discalceatorum Romae celebrati A. D. 1605, s. 3; Acta Capituli Generalis OCD Congregationis S. Eliae vol. I (1605-164I), ed. Antonius Fortes OCD, [w:] Monumenta Historica Carmeli Teresiani, t. 11, Romae 1990, s. 8.

${ }_{16}$ APKB, sygn. AP 1, Fasciculus annorum Provinciae Spiritus Sancti Carmelitarum Discalceatorum in Regno Poloniae, s. 12.

${ }_{17}^{17}$ B. J. W a n a t OCD, Zakon Karmelitów Bosych w Polsce, s. 56.

${ }_{18}^{18}$ Acta Capituli Generalis, op. cit., s. 65-66.

${ }^{19}$ Constitutiones Fratrum Discalceatorum Congregationis S. Eliae Ordinis Beatissimae Virginis Mariae de Monte Carmelo, Romae 1631, s. 98.

${ }^{20}$ Biblioteka Zakładu Narodowego im. Ossolińskich we Wrocławiu, rkps 1877/II, Acta primi capituli generalis Fratrum Carmelitarum Discalceatorum 1605-1729, s. 63; Acta Definitorii Generalis OCD Congregationis S. Eliae (1605-1658), ed. Antonius Fortes OCD, [w:] Monumenta Historica Carmeli Teresiani, subsidia 3, Roma 1985, s. 64.

${ }^{21}$ APKB, dypl. 11; B. J. W a n at OCD, Zakon Karmelitów Bosych w Polsce, s. 303, $341-344$ 
ciła klasztorowi krakowskiemu ŚŚ. Michała i Józefa w Krakowie do chwili rozpoczęcia życie pustelniczego w eremie w $1633 \mathrm{r}$.

Z powyższego wynika zbieżność czasowa, czyli paralelizm przybycia na stały pobyt do Polski w 1605 roku dwóch rodzin zakonnych oo. kamedułów i oo. karmelitów bosych, za zgodą tych samych władz kościelnych i na zaproszenie króla Zygmunta III Wazy. Fundatorami eremów byli magnaci, pragnący pomnożenia chwały Bożej i dobra Ojczyzny, a dla siebie zapewnienia modlitwy i codziennej ofiary mszy św. po śmierci oraz pochówku w krypcie przy wejściu za progiem świątyni, aby wchodzący mogli deptać po ich grobach.

\section{PARALELIZM WARTOŚCI IDEOWYCH}

Idea życia pustelniczego sięga II wieku po Chrystusie. Chrześcijanie pragnąc naśladować życie ukryte Jezusa a zwłaszcza Jego okres postu i pobytu na pustyni, udawali się na pustynie Egiptu, Palestyny i Syrii i żyli w samotności lub w grupach, oddając się modlitwie i pracy. Wzorem życia pustelniczego byli św. Paweł z Teb i św. Antoni. Z biegiem czasu powstawały całe osady eremitów w niewielkim oddaleniu od osiedli ludzkich. Centrum życie wspólnot stanowiła liturgia, na którą zbierali się mnisi w niedziele i święta. Utrzymywali się z jałmużny i z pracy. W XI wieku powstał pustelniczy Zakon Kamedułów na regule św. Benedykta, założony przez św. Romualda (954-1027) z eremem w Camaldoli w Apeninach. W wyniku przeprowadzonej reformy zakonu przez bł. Pawła Tomasza Justinianiego (1467-1528), nawiązującej do pierwotnego charyzmatu założyciela, z cenobickich i eremickich wspólnot wyodrębniła się w latach 1525-1530 Kongregacja Eremitów Kamedułów Góry Koronnej w Italii (k. Perugii) ${ }^{22}$ do której należały fundacje w Polsce.

Centralną wartością i zasadą życia pustelniczego wedhug nauki bł. Pawła jest obowiązująca dewiza: „żyć sam na sam z Bogiem i żyć dla Boga samego". Według konstytucji życie pustelnicze w zakonie kamedułów jest całkowicie nastawione na zjednoczenie $\mathrm{z}$ Bogiem w ustawicznej modlitwie i kontemplacji ${ }^{23}$.

Podstawowym środkiem do zrealizowania tej zasady jest przestrzeganie samotności ${ }^{24}$, milczenia i skupienia oraz przebywanie na modlitwie w celi. Cela stanowi obszar, w którym pustelnik żyje w obecności samego Boga oraz podejmuje studium Słowa Bożego i innych ksiagg pożytecznych dla duchowego rozwoju. Jest ona też miejscem pracy pustelnika. Opuszcza ją tylko dla sprawowania Eucharystii, liturgii godzin i dla wykonywania innych aktów wspólnotowych ${ }^{25}$.

Program dnia pustelników jest wypełniony modlitwa i praca. $\mathrm{O}$ godz. 3.45 dzwon z wieży kościelnej obwieszcza pobudkę do wstawania. $\mathrm{O}$ godz. 4.00 po-

${ }^{22}$ O. A. B i ału ch a EC, op. cit., s. 13-15; M. Daniluk, Kameduli, [w:] Encyklopedia katolicka, t. VIII, Lublin 2000, kol. 439-443.

${ }^{23}$ Konstytucje Kongregacji Pustelników Kamedutów Góry Koronnej, Kraków-Bielany 1991, s. 11.

${ }^{24}$ Reguta $i$ konstytucje, rozdz. I, nr 5.

${ }^{25}$ O. A. B i a łu ch a EC, op. cit., s. $17-19$. 
nownie wzywa ich na modlitwy do zakonnego chóru na godzinę czytań, dawniej odmawianą wraz z Jutrznią o pólnocy aż do II Soboru Watykańskiego. Po modlitwie zakonnicy udają się do cel na czytanie duchowe. O godz.5.45 odmawiaja w kościele Jutrznię i sprawują Liturgię Eucharystyczna, koncelebrowaną przez wszystkich kapłanów, a po jej zakończeniu odmawiają tercję. Od godz. 7-8 jest czas przeznaczony na śniadanie i czas wolny. Od godz. 8-11.30 obowiązuje praca fizyczna w milczeniu i skupieniu. O godz. 11.45 rozpoczyna seksta, a o godz. 12.00 Anioł Pański. Potem jest czas wolny do godz. 14.00 przeznaczony na obiad i odpoczynek. O godz. 14.. pustelnicy odmawiają w kościele nonę, a o godz. 16.30 różaniec. Kolacja jest o godz. 17.00 , a po niej czytanie duchowe w celi lub kościele. O godz. 18.30 odmawiają w kościele Nieszpory, potem litanię loretańską do NMP, Anioł Pański i czytanie duchowe. Na zakończenie dnia odmawiaja kompletę, modlitwę za zmarłych i różaniec. Po ich zakończeniu rozchodzą się do swoich cel na modlitwy indywidualne i na spoczyne ${ }^{26}$. Kameduli nie spożywają pokarmów mięsnych. Skromne posiłki spożywają w celach swoich. Przez cały czas zachowuja milczenie i skupienie. Rozmawiają tylko w czasie ważnej potrzeby i to na uboczu, głosem przyciszonym. Pięć razy do roku jest wielka rekreacja i w tym czasie mogą opuścić erem i udać się na wycieczkę ${ }^{27}$.

Zakon Karmelitów w swoich początkach na Górze Karmel w Palestynie był pustelniczy. Do grupy pustelników żyjących od V wieku przy źródle Eliasza dołączyli w XI wieku krzyżowy z Europy i zorganizowali ich w formalną wspólnotę zakonną. Uzyskali oni w 1209 r. od św. Alberta Avogadro, patriarchy jerozolimskiego regułę pustelniczą, zatwierdzoną przez pap. Honoriusza III w $1226 \mathrm{roku}^{28}$. $\mathrm{Z}$ powodu inwazji tureckiej na Palestynę karmelici musieli wyemigrować do Europy i tutaj musieli zmienić styl życia. W 1274 roku Sobór Lyoński II zatwierdzając Zakon Karmelitów zaliczył go do zakonów mendykanckich ${ }^{29}$. Reforma zakonu przez św. Teresę od Jezusa i św. Jana od Krzyża po Soborze Trydenckim, przywróciła pierwotną regułę zmodyfikowaną i zatwierdzoną przez pap. Innocentego IV w 1247 roku, dającą możliwość w Karmelu prowadzenia życia pustelniczego. Stąd w każdej prowincji karmelitów bosych w XVII i XVIII wieku znajdowal się erem.

Dewiza duchowego życia pustelników w Czernej określona została w regule karmelitańskiej:

Wszyscy bracia mają przebywać osobno w swoich celach lub przy nich, oddając się w dzień i w nocy rozważaniu Prawa Bożego i czuwaniu na modlitwach ${ }^{30}$.

${ }^{26}$ Zycie codzienne w klasztorze, http:// www. kameduli.pl/zycie.php.

${ }^{27}$ Porządek dnia opracowany na podstawie reguły i konstytucji ustala kapituła domowa i zatwierdza przełożony wyższy.

${ }^{28}$ Bullarium carmelitanum, ed. E. Monsignani et I. A. Ximenez Ord. Carm., t. I, Romae 1715 , s. 1 .

29 Monumenta Historica Carmelitana, volumen primum continens antiquas Ordinis constitutiones, acta Capitulorum Generalium..., ed. P. Benedictus Zimmerman, Lirinae 1907, s. 216-217.

${ }^{30}$ Regula, konstytucje, przepisy wykonawcze Zakonu Braci Bosych Najświętszej Maryi Panny z Góry Karmel, Kraków 1997, s. 24. 
$\mathrm{Na}$ każdy dzień przypominała ją inskrypcja na portalu wejściowym do świątyni, zaczerpnięta $\mathrm{z}$ dzieł św. Bernarda: Ipse Deus locum secretum quaerit. O beata solitudo, o sola beatitudo - (Sam Bóg szuka samotnego miejsca. O szczęśliwa samotności, o sama szczęśliwości). Celem było pogłębienie przyjaźni z Bogiem aź do zjednoczenia z Nim przez milość przemieniającą na drodze wiary. Podobnie jak Kameđuli mieli obowiązek zachować gorliwość zakonną i cały program dnia i przepisy zatwierdzone dla eremu w Czernej ${ }^{31}$. Szczególnie kładziono nacisk na zachowanie milczenia, skupienia, samotności i lekturę duchową oraz pracę. Zakonnicy prowadzili życie wspólnotowe. Uczestniczyli w klasztorze we wszystkich aktach liturgii godzin kanonicznych, we mszy św. konwentualnej, w modlitwie myślnej, rachunku sumienia, posiłkach we wspólnym refektarzu, w czasie którego lektor czytał Pismo św., żywoty świętych i przepisy zakonne. Brali też udział w tzw. kolacjach duchownych zwyczajnych i nadzwyczajnych. Były to konferencje duchowne na tematy teologiczne, liturgiczne i hagiograficzne. Każdy z pustelników mógł wypowiedzieć swoje zdanie na wcześniej ustalony temat. Wyznaczony sekretarz kapituły protokołowal poszczególne wypowiedzi. Zachowały się w archiwum dwa woluminy sprawozdań z kolacji zwyczajnych i nadzwyczajnych odbywanych $z$ okazji większych uroczystości z XVII i XVIII wieku $^{32}$. Kolacje w porze letniej odbywaly się w specjalnej kapliczce pod lipa, upamiętniająca fundatorkę klasztoru. Po nadzwyczajnych kolacjach mogli pustelnicy przez dwie godziny odbywać spacery na terenie wielkiej klauzury i rozmawiać ze sobą.

Pustelnicy w Czernej udawali się na indywidualne ćwiczenia duchowe na cały okres Adwentu i Wielkiego Postu do eremitoriów zbudowanych wokół klasztoru na wzniesieniach pasma góry czerneńskiej i siedleckiej, za rzeczką Eliaszówką. Termin ten z powodu zimnego klimatu za zgodą kapituły generalne w 1671 r. przesunięto na okres od oktawy Wielkanocy do Zesłania Ducha Świętego oraz 15 dni po uroczystości św. Teresy od Jezusa ${ }^{33}$. Tam odprawiali swoje ćwiczenia, łącząc się w porządku dnia ze wspólnota w klasztorze przez równoczesne dzwonienie na sygnaturkach swych pustelni $\mathrm{z}$ dzwonem $\mathrm{z}$ wieży klasztornej ${ }^{34}$. Tryb życia był surowy. W nocy od godz. 24 do 2 odmawiali brewiarz: matutinum i laudesy. Na odgłos dzwonu z wieży klasztornej udawali się z powrotem na spoczynek. Od godz. 5-6 odprawiali medytację. Po rozmyślaniu odmawiali prymę i tercję. O. godz. 10 była seksta, msza św. konwentualna, którą odprawiał hebdomadariusz oraz nona. $\mathrm{O}$ godz. 11.30 był obiad. W czasie pobytu w eremitoriach pustelnicy sami przygotowywali sobie posilki. Raz w tygodniu, wyznaczony brat

${ }^{31}$ Instructiones eremi Fratrum Discalceatorum Congregationis Sancti Eliae Ordinis Beatissimae Virginis Mariae de Monte Carmelo, Romae 1672, Reimpressum Cracoviae, Typis Collegii Majoris Anno Domini 1737.

${ }_{32}$ APKB, rkps 50, Collationes ordinariae et extraordinariae eremitarum conventus sub tit. S. Eliae Czernae (1673-1685); Rkps 51, Liber collationum ordinariarum et extraordinariarum Conventus s. Eremi Carmelitarum Discalceatorum (1717)

${ }^{33}$ APKB, sygn. AKC 17, Notata de caeremoniis consuetudinisque huius S. Deserti aplicata usui PP. Eremitarum caeremoniis rite observare studentium, s. 81 .

${ }^{34}$ Instructiones Eremi Fratrum Discalceatorum Congr. S. Eliae Ordinis Beatissimae Virginis Mariae de Monte Carmelo, Romae 1669, s. 91-93. 
roznosił im żywność. Przychodząc w sobotę do klasztoru na odśpiewanie w białych płaszczach uroczystej antyfony Salve Regina przed ołtarzem Matki Bożej oraz w niedzielę na konwentualną kapitułę, przynosili ze sobą torby $z$ adresem danego eremitorium. Torby zostawiali przy bramie klasztornej, a przełożony wydzielał im aprowizację. Po obiedzie przez 45 minut pustelnicy spędzali czas na spacerze w lesie. W eremie obowiązywało ścisłe i wieczne milczenie. Można było rozmawiać tylko z przełożonym, który był równocześnie kierownikiem duchowym pustelników. Między sobą pustelnicy porozumiewali się jedynie znakami i pismem. O godz. 14 odmawiali nieszpory z litanią do Matki Bożej. Od godz. 17-18 odbywało się rozmyślanie, następnie kompleta, kolacja, rachunek sumienia i modlitwy wieczorne. Różaniec każdy odmawiał indywidualnie. Porządek dnia ulegał zmianie $w$ dni świąteczne, postne $\mathrm{i}$ bezpostne. Poza tym porządkiem w rozkładzie dnia przewidziany był czas na pracę ręczną oraz na lekturę duchowa. W klasztorze spożywano dziennie dwa bezmięsne posiłki: obiad i kolację. Po obiedzie i dziękczynieniu, całe zgromadzenie z przełożonym na czele udawało się do kuchni i zmywało naczynia, talerze, wazy i garnki, odmawiając wspólnie psalm 50 Miserere mei Deus. Po zakończeniu tej czynności zakonnicy udawali się na nawiedzenie Najśw. Sakramentu do kościoła, a następnie w milczeniu do cel ${ }^{35}$.

Porządek dnia w obu eremach był bardzo podobny, z tą różnica, że pustelnicy w Czernej spożywali posiłki wspólnie w refektarzu poza czasem ich pobytu w oddzielnych domkach pustelniczych oraz spotykali się razem w czasie kolacji duchownych. Łączyło oba zakony szczególne nabożeństwo do Matki Bożej Patronki obu Zgromadzeń. Pustelnicy z Bielan zobowiązani byli codziennie wspólnotowo odmawiać różaniec, podczas gdy pustelnicy w Czernej odmawiali go prywatnie. $\mathrm{Na}$ Bielanach zakonnicy zobowiazani byli do codziennego odmawiania officium małego o Najśw, Maryi Pannie ${ }^{36}$. Zakonnicy zaś w Czernej codziennie odprawiali mszę św. wotywną o Niepokalanym Poczęciu NMP, jako obligację wieczystą za fundatorkę z wyjątkiem uroczystości, za zgodą Stolicy Apostolskiej ${ }^{37}$.

Eremy na Bielanach i w Czernej pełniły rolę duchowych bastionów życia wiary i były jasnymi pochodniami życia Bogu oddanego, rozświetlające mroki niewiary. Pustelnicy swą modlitwą i ofiarą wypraszali błogosławieństwo Boże całej Ojczyźnie. Stąd do tych eremów garnęli się na rekolekcje kapłani, biskupi i królowie. Ci ostatni często przybywali polecać modlitwie sprawy całej Ojczyzny. Dzieje klasztoru zanotowały pobyt króla Władysława IV, fundatora kaplicy na Bielanach oraz Jana Kazimierza we wrześniu 1655 roku, gdzie nocował przed ucieczką przed Szwedami na Śląsk. Stąd miał obserwować płonące przedmieścia Krakowa , które dowódca wojska polskiego Stefan Czarniecki polecił spalić, aby utrudnić Szwedom zdobycie Krakowa (Jan Matejko na płótnie utrwalił tę scenę) ${ }^{38}$.

${ }^{35}$ B. J. W a n a t OCD, Zakon Karmelitów Bosych w Polsce, s. 310.

${ }^{36}$ Reguta sw. Benedykta i Konstytucje Zgromadzenia..., rozdz. XIX, nr 3, s. 98.

${ }^{37}$ APKB, sygn. AKC 17, Notata de caeremoniis consuetudinibusque huius S. Desert, s. 97.

${ }^{38}$ Kameduli $w$ Polsce, przerobione z dzielka Ludwika Zarewicza pod tytułem: Zakon Kamedulów, jego fundacje i dziejowe wspomnienia w Polsce i Litwie, w Krakowie 1871. Zakłady graficzne E. Dr K. Koziańskich w Krakowie [b. D.], s. 28. 
14 sierpnia 1683 roku przed odsieczą Wiedeńską król Jan III Sobieski brał udział w uroczystym nabożeństwie w kościele na Bielanach. Dnia 27 X 1698 roku przebywała w eremie królowa Maria Kazimiera, wdowa po królu Janie III Sobieskim $^{39}$. Podobnie król August II odprawiał tutaj swoje rekolekcje w 1706, a nominat prymas gnieźnieński ks. Adam Komorowski w 1749 roku $^{40}$.

Również w eremie w Czernej odprawiała swoje ćwiczenia duchowe fundatorka Agnieszka Firlejowa, kanonik krakowski ks. Wawrzyniec Gembiski († 1652) oraz król Jan Kazimierz spędził na ćwiczeniach duchowych cały Adwent 1660 roku, a jego małżonka Maria Ludwika odprawiała swoje rekolekcje w tym też czasie w klasztorze św. Marcina ss. karmelitanek bosych w Krakowie przy ul. Grodzkiej $^{41}$. Także ostatni król Polski, Stanisław August Poniatowski, miłośnik sztuk pięknych, w 1787 roku odbył podróż do Krakowa, zwiedził zarówno erem oo. kamedułów na Bielanach ${ }^{42}$, jak również erem karmelitów bosych w Czernej oraz ich kamieniołom czarnego marmuru w Dębniku ${ }^{43}$. Do pustelników w Czernej przybywali też niekiedy w czasie wielkiej rekreacji Kameduli z Bielan na duchowe rozmowy i wspólne spotkania „Ojców Pustyni”.

Stolica Apostolska zawsze doceniała ideowe wartości życia kontemplacyjnego. W dokumencie Kontemplacyjny wymiar życia zakonnego Kongregacji Zakonów i Instytutów Świeckich życia Konsekrowanego z 1980 r. czytamy:

Wezwani do życia specyficznie kontemplacyjnego uznani są za jeden z najbardziej drogocennych skarbów Kościoła. Oni to dzięki szczególnemu charyzmatowi, wybrali najlepszą cząstkę (por. Łk 10,42), a mianowicie cząstkę modlitwy, milczenia, kontemplacji, wyłącznej miłości Bogu i całkowitego oddania się na Jego służbę... Kościół bardzo liczy na ich duchowy wkład. Instytuty te, zachowują zawsze, choćby nagliła konieczność czynnego apostolstwa, wyborną cząstkę w Mistycznym Ciele Chrystusa... Bogu składają doskonałą ofiarę a Ludowi Bożemu dodają blasku przez obfite owoce świętości, zagrzewają go przykładem i przyczyniają się do jego wzrostu, dzięki tajemniczej płodności apostolskiej. Dlatego też powinni z całym realizmem przeżywać tajemnicę „Pustyni”, na która zaprowadziło ich „Wyjście”. Jest to miejsce, w którym pośród walki z pokusą niebo i ziemia - według tradycji spotykają się ze sobą i w którym świat - ziemia wyschła - staje się rajem... a sama ludzkość osiaga swą pełnię" (nr 25).

Tę piękną ocenę życia kontemplacyjnego, należało przypomnieć z okazji jubileuszu 400-lecia praktykowania tego życia przez OO. Kamedulów na Bielanach.

${ }^{39}$ O. A. B i a łu ch a EC, op. cit., s. 29.

${ }^{40}$ Tamże, s. 31.

${ }^{41}$ Klasztory Karmelitanek Bosych w Polsce, na Litwie i Rusi. Kraków, I klasztor św. Marcina, Kraków 1904, s. 108.

${ }^{42}$ O. A. B i a f u c h a EC, op. cit., s. 31.

${ }^{43}$ B. J. W a n a t OCD, Maryjne sanktuarium karmelitów bosych $w$ Czernej, Kraków 1992, s. 132-135. 


\section{PARALELIZM WARTOŚCI ARTYSTYCZNYCH}

\section{Erem na Bielanach}

Projekt architektury przestrzenno kompozycyjnej klasztoru był przywieziony przez marszałka wielkiego koronnego Mikołaja Wolskiego z Italii w 1602 roku i tam opracowany, według własnych przepisów budowlanych, uwzględniających charyzmat, potrzeby i styl życia Zakonu Kamedułów ${ }^{44}$. Szczegółowe przepisy budowy eremów i kościołów dla zakonu opracowane zostały dopiero na kapitułach generalnych w latach 1607 i 1608 i zatwierdzone jako obowiazzująca norma w 1610 roku $^{45}$. Przygotowany projekt eremu dla Bielan prawdopodobnie był powtórzeniem schematu eremu w Rocca di Garda z Italii, ale nie objęty jeszcze ścisłymi wymiarami instrukcji budowlanej, która weszła w życie dopiero w 1610 roku czyli po wybudowaniu już domków eremickich. Podobny był do kościoła Kamedułów w Rytwianach, a jego makieta na obrazie Matki Bożej z Dzieciątkiem i śś. Benedykta i Romualda utrwalona została przez zakonnego malarza Wenantego $\mathrm{z}$ Subiaco ${ }^{46}$. Według opracowanej instrukcji budowlanej kościoły miały być jednonawowe, skromne, bez ozdób i porządków architektonicznych, pośrodku długiego prezbiterium miał być ołtarz jedyny w kościele a za nim chór zakonny. Węższe od nawy prezbiterium miała flankować $\mathrm{z}$ południowej strony zakrystia $\mathrm{z}$ ołtarzem, a przed nią przedsionek $\mathrm{z}$ wieżą zegarową i dzwonnica, przylegającą do prezbiterium. $Z$ północnej zaś strony miał być kapitularz a nad nim biblioteka. Po obu stronach nawy kościoła miały być zamykane kaplice $z$ ołtarzami po jednej $z$ każdej strony ${ }^{47}$.

Budowę klasztoru rozpoczęto w 1604 r. od niwelacji wzgórza i przygotowania terenu oraz jego zabezpieczenia przed obsuwaniem się od strony południowej i wykopania studni głębokiej ok. $70 \mathrm{~m}$. od strony północnej, w pobliżu zaplanowanej kuchni. W 1605 r ks. kard. Bernard Maciejowski, bp krakowski, poświęcił kamień węgielny pod budowę 20 domków eremickich w czterech rzędach, usytuowanych w południowo wschodniej części wzniesienia, za wschodnią ścianą prezbiterium kościoła. Każdy domek pustelniczy posiada 4 pomieszczenia oddzielone sienia. $\mathrm{Z}$ lewej strony cela zakonna i pracownia, z prawej strony kaplica $\mathrm{z}$ ołtarzy-

${ }^{44}$ Regula św. Benedykta i konstytucye Zgromadzenia Kamedulów-Pustelników z Góry Koronnej, przejrzane i potwierdzone przez Ojca św. Klemensa IX, podtug wydania wtoskiego w Rzymie R. P. 1670, przettumaczone na język polski R. P. 1912, Kraków 1912, s. 278-379.

${ }^{45}$ P. T. L u ga no, La Congregazione camaldolese degli eremiti di Montecorona dalle origini ai nostri tempi, Roma-Frascati 1908, s. 354; A. M a l k i e w i c z, Zespól architektoniczny na Bielanach pod Krakowem (1605-1630), [w:] Zeszyty Naukowe Uniwersytetu Jagiellońskiego, Prace z historii sztuki, z. 1, Kraków 1962, s. 149, 180; Tenże, Z historycznej $i$ artystycznej problematyki kościola Kamedulów na Bielanach pod Krakowem, [w:] Zeszyty Naukowe Uniwersytetu Jagiellońskiego. Prace z historii sztuki, z. 10, Kraków 1972, s. 95.

${ }^{46} \mathrm{~A} . \mathrm{M}$ i ło b ęd z k i, Z historycznej $i$ artystycznej problematyki Kościola Kamedutów na Bielanach pod Krakowem, [w:] Zeszyty Naukowe Uniwersytetu Jagiellońskiego $\mathrm{nr}$ CCCII, Prace z historii sztuki, z. 10, Kraków 1972, s. 90, rys. 1.

${ }^{47}$ Zob. P. T. Lu g a n o, op. cit. s. 345; A. M a ł k i e w i c z, Z historycznej $i$ artystycznej problematyki..., op. cit. s. 96 . 
kiem, a obok niej komórka na składzik. Każdy domek był murowany i pokryty dachem siodłowym. Przy każdym z nich był ogródek otoczony murem.

Zanim wyposażono wnętrza domków eremickich dnia 4 maja 1609 r. nuncjusz apostolski Franciszek Simonetta poświęcil plac pod budowę świątyni. Budowa pierwotnego kościoła według planu zbliżonego do macierzystej świątyni w Monte Corona trwała do 1617 roku przez nieznanego architekta. W tym roku erem podniesiono do godności przeoratu. Zakonnicy mieszkali w nim już od 1610 roku. Dalszą budowę kościoła przerwała katastrofa budowlana późną jesienią $1617 \mathrm{roku}^{48}$. Zawaliła się spora część kościoła. Wtedy fundator Wolski sprowadził z Czech włoskiego architekta Andrzeja Spezzę, któremu zlecił dalszą budowę świątyni. Odstappił on od pierwotnej koncepcji i zaplanował szeroką nawę na wzór kościoła il Gesu z rzędami kaplic po bokach w układzie bazylikowym, z monumentalną fasadą kamienną flankowaną dwiema wieżami. Wykonali ją kamieniarze Tomasz Mrozek i Giacomo Materni. Dzieje budowy i architekturę kościoła oraz jej analizę formalną i stylistyczno porównawczą opracowali naukowo Stanisław Tomkowicz $^{49}$, Adam Małkiewicz ${ }^{50}$ i Wojciech Kret $^{51}$. Architektów, rzeźbiarzy, malarzy, kamieniarzy i snycerzy oraz stolarzy zatrudnionych przy budowie ustalił na podstawie archiwalnych źródeł klasztoru Jacek Gajewski ${ }^{52}$.

Równocześnie z pracami dekoracyjnymi w kościele i budową fasady wznoszono w latach 1620-1630 zabudowania klasztorne wokół dziedzińców klasztornych i przy furcie, wytyczano wewnętrzne alejki oraz wznoszono mury małej i dużej klauzury według projektu Andrzeja Spezzy ${ }^{53}$. W pracach budowlanych zatrudnieni byli jeszcze dwaj architekci Jan i Jakub znani tylko $\mathrm{z}$ imienia oraz budowniczy Jan Maria Spinelli z Włoch ${ }^{\text {54 }}$. Dnia 9 IX 1630 roku w Przemyślu zmarł fundator klasztoru Mikołaj Wolski. Dwa dni wcześniej (7 IX) w testamencie zapisał jeszcze kamedułom wsie: Malec i Ryczów, kamienicę przy ul. Gołębiej w Krakowie na hospicjum dla zakonników oraz sumę czynszową 1500 zł na dobrach rybotyckich. Pochowany został zgodnie z życzeniem w krypcie grobowej przy wejściu do świątyni na Bielanach. Na płycie grobowej polecił umieścić napis zachowany do obecnej chwili: DUM VENERIS IUDICARE, /COMMISSA/MEA

${ }^{48}$ L. Z a r ew i c z, op. cit., s. 23.

${ }^{49}$ S. T o m k o w i c z, Bielany, Kraków 1904; Tenże, Bielany, [w:] Powiat krakowski, Teka Grona Konserwatorów Galicji Zachodniej, Kraków 1906, II, s. 6-52.

${ }^{50}$ A. M ałk i ew ic z, Zespót architektoniczny na Bielanach pod Krakowem (1605-1630), [w:] Zeszyty Naukowe Uniwersytetu Jagielońskiego. Prace z historii sztuki, nr 45, z. 1, Kraków 1962, s. 143-183; Tenże, Z historycznej $i$ artystycznej problematyki kościola Kamedulów na Bielanach pod Krakowem, [w:] Zeszyty naukowe Uniwersytetu Jagiellońskiego. Prace z historii sztuki, z. 10, Kraków 1972, s. 83-107.

${ }^{51}$ W. Kret, Problematyka artystyczna kościola OO. Kamedutów na Bielanach pod Krakowem. Geneza - charakterystyka - oddziatywanie, „Kwartalnik Architektury i Urbanistyki”, t. XII, z. 3-4, Warszawa 1967, s. 23-55.

${ }^{52}$ J. G aj e w sk i, Kościól i klasztor kamedulów na Bielanach pod Krakowem w świetle materiatów archiwalnych, „Biuletyn Historii Sztuki”, R: XXXVIII, nr 1, 1976, s. 374-377 Tenże, Prace Antoniego Frqczkowicza dla Zakonu Kamedulów. Ze studiów nad rzeźba polowy XVIII wieku w Matopolsce, BHS, R. XLI, nr 4 (1979), s. 363-387.

${ }^{53}$ J. G a j e w s k i, Kościót i klasztor kamedułów..., s. 374.

54 Tamże. 
PAVESCO ET ANTE TE/ ERUBESCO./ DOMINE, NOLI ME CONDEMNARE! . $^{55}$ Kapituła klasztorna z wdzięczności dla swojego fundatora zobowiązała się codziennie za jego duszę odprawiać jedną mszę św., a w rocznicę jego pogrzebu 10 marca uroczysty anniwersarz ze wszystkimi mszami ${ }^{56}$. W $1631 \mathrm{r}$. z inicjatywy wizytatora generalnego o. Sylwana Bosello umieszczono nad wejściem epitafium fundatorowi, zaprojektowane i wykonane przez włoskiego rzeźbiarza i sztukatora Andrzeja Castellego ${ }^{57}$. Poniżej epitafium nad bramą wejściową kościoła umieszczono naturalnej wielkości portret fundatora, przypisany malarzowi kamedulskiemu o. Wenantemu z Subiaco ${ }^{58}$. Ten artysta wloski w latach 1624-1625 wymalowal cały szereg obrazów: scenę Zwiastowania w kaplicy przylegającej do zakrystii, scenę Ukrzyżowania w kapitularzu, obrazy dekorujące chór i wystrój malarski kaplic oraz uduchowiony i piękny wizerunek Matki Bożej Patronki Pustelników, umieszczony w predelli ołtarza w kaplicy św. Romualda ${ }^{59}$. Przy dekoracji kaplic kościoła brali udział inni malarze: Daniel, Jan Chryzostom Proszowski, Tomasz Dolabella, Stanisław Boja, Jan Koy, Piotr Brygierski i Paweł Pieleszyński oraz sztukatorzy - Dominik i Hieronim, Philibert i znakomity artysta Jan Chrzciciel Falconi. Prace rzeźbiarskie i snycerskie wykonywali Jan Szabura, Sebastian Sala, Jerzy Zimmerman, Mikołaj Radoszowicz, Kasper Kromlauff i Antoni Frączkowicz w XVIII wieku ${ }^{60}$.

Fundatorami wystroju i wyposażenia bocznych kaplic byli: król Władysław IV w 1632 r. kaplicy śś. Władysława, Benedykta i Bonifacego z obrazami T. Dolabelli; wojew. Krakowski Stanisław Lubomirski kaplicy św. Sebastiana w 1642 r. ( $z$ marmurowym ołtarzem w dolnej kondygnacji prawej wieży wg projektu Fr. Placidiego); Rafał del Pace, rajca krakowski, wyposażył kaplice: św. Romualda z obrazem T. Dolabelli i śś. Jana Chrzciciela ${ }^{61}$ i Jana Ewangelisty; Kaplica św. Anny Samotrzeciej; kaplica św. Piotra; Kaplica św. Michała Archanioła (z malarską dekoracją P. Brygielskiego) i kaplica św. Krzyża Czartoryskich, z marmurowym ołtarzem w przyziemiu lewej wieży, według projektu Franciszka Placidiego. W 1 poł. XVIII w. w królewskiej kaplicy pierwotny ołtarz rzeźbiarza Jerzego Zimmermana zastapiono nowym, wykonanym przez Antoniego Frączkowicza z obrazem śś. Bonifacego, Władysława i Benedykta, namalowanym przez Szymona Czechowicza, a w kaplicy św. Romualda barokowy ołtarz wykonal w $1731 \mathrm{r}$. Jan Eliasz Hoffman ${ }^{62}$.

${ }^{55}$ Kiedy przybędziesz sądzić, strach mnie ogarnia za występki moje i wstydzę się przed Tobą. Panie, nie chciej mnie potępić!

${ }_{57}^{56}$ L. Z a r ew i c z, op. cit., s. $224-225$.

${ }^{57}$ J. G a j e w sk i, Bielańskie epitafium Mikotaja Wolskiego i projekt Andrzeja Castellego, BHS, R: XXXIX, nr 2(1977), s. 143-155.

${ }^{58}$ L. Z a rew ic $z$, op. cit., s. 226.

${ }^{59}$ A. B i a łu ch a EC, op. cit., s. 27.

${ }^{60} \mathrm{~J} . \mathrm{G}$ a j e w s k i, Kościót i klasztor kamedułów ma Bielanach..., s. 375-376.

${ }^{61}$ Scena chrztu Chrystusa odbywa się w nurtach Wisły z widokiem klasztoru na Bielanach i w panoramie Krakowa $z$ Wawelem.

62 J. G aj e w s k i, Kościót i klasztor kamedutów na Bielanach..., s. 376; W. K r e t, op. cit., s. 24; J. Gaj ews k i, Prace Antoniego Fraczkowicza dla zakonu kamedutów..., s. 365, 
Oficjalnym i uroczystym aktem przekazania nowej świątyni do publicznego kultu Bożego była jej konsekracja w dniu 14 września 1642 r. pod wezwaniem Wniebowzięcia NMP, przez Tomasza Oborskiego, biskupa pomocniczego z Krakowa ${ }^{63}$.

Kościól na rzucie prostokąta $z$ jedną szeroką nawą nakrytą sklepieniem kolebkowym na gurtach, z rzędami kaplic bocznych, szerokimi archiwoltami otwierających się do nawy i komunikujących się wąskimi przejściami, prezentuje wysoki poziom architektury manierystycznej. Elewacje nawy i prezbiterium rozczłonkowane są pojedynczymi pilastrami z jońskimi kapitelami, dźwigającymi regularne belkowanie, których woluty spinają girlandy z główkq putta. Prezbiterium węższe, usytuowane o cztery stopnie wyżej od nawy i oddzielone tralkowa balustradą z czarnego marmuru z Dębnika, flankowane jest zakrystią od strony południowej z kaplica Zwiastowania NMP i kapitularzem od strony północnej. Z przedsionków zakrystii i kapitularza prowadzą schody na empory nad bocznymi kaplicami z małymi okienkami do nawy kościoła. Nad południową kruchtą wznosi się dzwonnica-wieża zegarowa z cebulastą kopułą i latarnią. Pośrodku prezbiterium główny ołtarz z bramkami do chóru zakonnego, z nastawą ołtarzową z obrazem Wniebowzięcia NMP w retabulum, namalowanym przez Michała Stachowicza, po spaleniu się głównego ołtarza wraz z chórem zakonnym i dzwonnicą w 1814 r. Pod prezbiterium kaplica Pięciu Braci św. męczenników z Kujaw (zamordowanych w 1003 r.) i krypty grobowe zakonników. Kościół pozbawiony jest chóru muzycznego. Fasada kamienna, dwukondygnacyjna, trójosiowa, zwieńczona trójkątnym przyczólkiem ze statuą Niepokalanej, z artykulacją pionowych pilastrów, poziomych gzymsów, otworów okiennych i nyż ze statuami śś. Benedykta i Romualda w dolnej kondygnacji, śś. Jana Kantego, Mikołaja, Bonifacego i Jana Nepomucena w górnej kondygnacji, wykonanymi przez rzeźbiarza Józefa von Cara. Fasadę wydłużają i flankują wysunięte nieco do przodu trzykondygnacyjne wieże $\mathrm{z}$ barokowymi hełmami (kopułami) i latarniami.

Charakterystyczną cechą przestrzennej kompozycji architektury klasztoru bielańskiego jest jego układ osiowy, organizujący wzdłuż osi dojazd do klasztoru, furtę, dziedziniec przed kościołem, kościół i eremitorium za elewacją szczytową prezbiterium $^{64}$.

\section{b) Erem Karmelitów Bosych w Czernej}

Eremicki klasztor karmelitów bosych pod wezw. Proroka Eliasza został zbudowany w latach 1629-1640 na stoku góry czerneńskiej, z fundacji Agnieszki z Tęczyńskich, wojewodziny krakowskiej ${ }^{65}$. Po zakupieniu tego gruntu od wieśnia-

371; Z. P r ó s z y ń s k a, Hoffman, [w:] Stownik artystów polskich, t. III, Wrocław-Warszawa-Kraków-Gdańsk 1979, s. 87.

${ }^{63}$ Upamiętnia ten akt konsekracji marmurowa tablica z obszerną inskrypcja, umieszczona w kruchcie zakrystii i prezbiterium.

${ }^{64}$ M. K a r p ow ic z, Barokw Polsce, Arkady 1988, s. 279; A. M i ł o b ę d z k i, Architektura XVII wieku, Warszawa 1980, s. 124-128; T. Chrzan ow s k i, M. K o r n e k i, Sztuka Ziemi Krakowskiej, Kraków 1982, s. 336-341; W. E. R a d z i k o w s k i, Kraków dawny i dzisiejszy, Kraków 1902, s. 182-186.

${ }^{65}$ B. J. W a n a t OCD, Zakon Karmelitów Bosych w Polsce, s. 301-346. 
ków z Czernej przez Jana Tęczyńskiego, brata fundatorki, zbocze góry zostało w roku 1628 zniwelowane i przygotowane pod budowę ${ }^{66}$. Od strony wschodnio południowej wykonano mocne podmurówki $z$ kamienia, aby zapobiec obsuwaniu się nasypu ziemi. Te umocnienia i podmurówki są jeszcze widoczne obecnie w narożach kwadratu.

Klasztor zbudowano według planu nieznanego nam architekta $w$ kształcie czworoboku o oryginalnym założeniu, przypominającym Escorial - rezydencje królewską $\mathrm{w}$ Hiszpanii ${ }^{67}$. Pierwotnie $\mathrm{z}$ trzech stron był parterowy, zaś od strony zachodniej piętrowy. W roku 1923 nadbudowano mieszkalne piettro od strony południowej $^{68}$, a w 1948 roku od strony wschodniej i północnej ${ }^{69}$. Boki kwadratu klasztoru mają po $70 \mathrm{~m}$. długości, z tym że skrzydło zachodnie przedłużono o 7,87 m. poza kwadrat budynku w stronę studni. Budynek jest murowany $z$ miejscowego kamienia i cegły, otynkowany, z trzech stron podpiwniczony, zachodnie skrzydło osadzone jest na skale. Zgodnie z przepisami reguły „w pośrodku cel” czyli kwadratu klasztornego znajduje się kościół wczesnobarokowy, jednonawowy, na rzucie krzyża lacińskiego, pod wezw. św. Eliasza. W przedłużeniu jednoprzęsłowego prezbiterium jest chór zakonny, a za nim wieża zegarowa $\mathrm{z}$ dzwonami, zwieńczona barokowym hełmem $\mathrm{i}$ latarnią. $\mathrm{W}$ przedlużeniu zaś ramion transeptu po prawej stronie mieści się zakrystia, a po lewej sala - magazyn kościelny z atinencjami, tworząc pośrodku cztery czworoboczne podwórza wewnętrzne. Elewacje jego rozczłonkowane są toskańskimi pilastrami, w krzyżu kościoła zdwojony$\mathrm{mi}$, ożywione tryglifami $\mathrm{w}$ regularnym belkowaniu, dźwigającym profilowany gzyms. Sklepienia kolebkowe, a na skrzyżowaniu transeptu krzyżowe, pokryte sztukaterią w formie figur geometrycznych. Wnętrze oświetlone 10 oknami w lunetach. Posadzka biało-czarna, marmurowa. Architektura zewnętrzna skromna bez artystycznej artykulacji. Elewacje gładkie tylko pod dachem siodłowym belkowanie z gzymsem wspartym na ciosowych konsolach. Dachy pokryte były blacha miedzianą $z$ barokową sygnaturką nad skrzyżowaniem naw. Wnętrze świątyni ozdobiono pięcioma portalami, trzema barokowymi ołtarzami, sześcioma konchowymi niszami po bokach ołtarzy, kandelabrami i balustradą wykonanymi z czamego marmuru dębnickiego.

Główny ołtarz, wczesnobarokowy, ujęty w architekturę dwóch kolumn z jońskimi głowicami na podwójnych cokołach, dźwigających regularne belkowanie z przerywanym przyczółkiem. W zwieńczeniu nasadnik z prostokątnym obrazem $(90$ x $88 \mathrm{~cm})$ proroka Eliizeusza z krzyżem na szczycie. Mensa na trzech stopniach. Antepedium misternie wykonane $\mathrm{z}$ rytą dekoracją roślinno-kwiatową na wzór tkaniny. Wielkie retabulum, zwieńczone oprofilowaną arkadą z kluczem, mieści olejny obraz $(170 \times 250 \mathrm{~cm})$ proroka Eliasza na pustyni. Obrazy namalował Tomasz Dolabella, nadworny malarz króla Władysława IV. Ołtarz był wykonany

${ }^{66}$ Archivio Generale dei Carmelitani Scalzi, Roma, Corso d'Italia 38, Plut. 92, i: S. Eremi Siedlec (Czerna) - Origo fundationis A. D 1625, s. 4.

${ }^{67}$ M. B r y k ow ska, Pustelnia w Czernej, BHS, R. XLIII, nr 2:1981, s. 172-175; T. Chrzanowski, M. Korne cki, op. cit, s. 341-343.

${ }_{68}$ AKC 11, O. Jan Kanty O s i e rd a OCD, Czerna, s. 1570-1578.

${ }^{69}$ AKC 6, Kronika klasztoru OO. Karmelitów Bosych w Czernej, s. 392. 
w warsztacie włoskich artystów Bartłomieja Stopano i Szymona Spadi (Spadka) w Dębniku.

Boczne ołtarze Matki Bożej Szkaplerznej i św. Teresy od Jezusa usytuowane w ramionach transeptu, barokowe, wykonane pod kierunkiem Adama Negowicza, mistrza kamieniarskiego w latach 1655-1657, natomiast grawerowane antepedia z ornamentem roślinnym prawdopodobnie wykonał Wojciech Zielaski. Nastawy, ujęte $\mathrm{w}$ architekturę dwóch kolumn $\mathrm{z}$ korynckimi kapitelami na tle pilastrów, podtrzymują regularne belkowanie z przerwanymi, uszatymi przyczółkami i owalnymi nasadnikami z krzyżem w zwieńczeniach. Po bokach spływy z wolutami. Laskami słynący obraz Matki Bożej Szkaplerznej na blasze miedzianej i św. Teresy na płótnie namalował Paweł Gołębiowski, a tonda Boga Ojca i św. Józefa w nasadnikach malował Tadeusz Kuntze ${ }^{70}$.

Brak fasady kościoła zrekompensowany został wspaniały portalem wejściowym od strony wnętrza świątyni. Wykonany został w tym samym czasie co główny ołtarz marmurowy, barokowy, architektoniczny z dwiema kolumnami na wysokich cokołach $\mathrm{z}$ jońskimi głowicami, dźwigającymi regularne belkowanie z przerwanym przyczółkiem, pośrodku którego herb Topór i orzeł dwugłowy Firlejów i Tęczyńskich. Na szczycie znajdował się nasadnik z krzyżem usunięty w XIX wieku. Nad portalem wisiał naturalnej wielkości olejny portret fundatorki Agnieszki z Tęczyńskich Firlejowej na tle ufundowanego eremu.

Kościół konsekrował 21 września 1640 r. biskup Piotr Gembicki z udziałem fundatorki klasztoru ${ }^{71}$. Cztery lata później zmarła fundatorka. Po uroczystym pogrzebie, zgodnie z jej wolą ciało pogrzebano w krypcie przy wejściu do kościoła $\mathrm{z}$ napisem na płycie:

\section{J. + M. \\ PANIE}

DAJ MI MIEJSCE Z OWIECZKAMI/ NIE ODLĄCZAJ MNIE Z KOZLAMI/ NA PRAWICY POSTAW ZE SLUGAMI/ AGNIESZKA, HRABIANKA Z TĘCZYNA FIRLEJOWA/, WOJEWODZINA KRAKOWSKA/ TEJ ŚWIĘTEJ PUSTELNI FUNDATORKA/ NAJHOJNIESZA DOBRODZIEJKA/ UBOGICH ZAKONNIKÓW I DUCHOWIEŃSTWA,/ PO SZEŚCIESIATYM SZÓSTYM ROKU/ SWEGO ŻYCIA/ CZTERDDZIESTYM SIÓDMEM SWEGO WDOWIEŃSTWA/ ROZTALA SIĘ Z TYM ŚWIATEM DNIA 16 CZERWCA/ ROKU PAŃSKIEGO MDCXLIV./ KTOKOLWIEK TĘDY PRZECHODZISZ DLA MODLITWY,/ WESTCHNIJ NABOŻNIE: O ŁASKAWY JEZU PANIE/ DAJ JEJ WIECZNE SPOCZYWANIE. AMEN.

W pobliżu tego grobu, na ścianie obok wyjściowego portalu, zakonnicy z wdzięczności dla swojej fundatorki wmurowali marmurową płytę, zawierającą wieczyste zobowiązania dla niej: codziennie trzy msze święte, a w rocznice jej śmierci uroczysty anniwersarz, dyscyplinę w każdy piątek, codziennie 1 godzinę modlitwy myślnej i litanię do Matki Bożej.

${ }^{70} \mathrm{~W}$ czasie renowacji ołtarza Matki Bożej w 1988 r. autor zauważył na odwrociu tonda Boga Ojca napis: „pinxit T. Konicz [Kuntze]”. Napis ten później przez nieuwagę konserwatora zmyto.

${ }^{71}$ Uroczystą konsekrację dokumentuje marmurowa tablica umieszczona pod chórem muzycznym kościoła. 
Klasztor w swym oryginalnym założeniu ermickim posiadał 16 mieszkań pustelniczych, złożonych $\mathrm{z}$ celi zakonnej, przedsionka i pracowni. Z krużganków obiegających wewnętrzne dziedzińce były wejścia w obramieniach kamiennych do sieni oraz przejściowe na zewnątrz do oddzielnych ogródków otoczonych ze wszystkich stron murem przed celami pustelniczymi, podobnie jak na Bielanach, w których zakonnicy uprawiali warzywa i kwiaty ${ }^{72}$. Krużganki ozdobione zostały w poł. XVIII w. galerią tablicowych obrazów Pawła Gołębiowskiego, przedstawiających sceny maryjne i św. pustelników oraz stacje Drogi Krzyżowej.

\section{PARALELIZM WARTOŚCI PRZESTRZENNYCH EREMU}

Konstytucje OO. Kamedułów z XVII wieku wymagały, aby przy przyjmowaniu nowych fundacji zwracać uwagę na położenie i samotność. „Muszą owe miejsca być zwrócone na południe i na wschód, a nigdy na północ. Lasy powinny mieć obszerne i gęste i obfitość wody. Będzie bardzo pożądanym, aby położenie miejsca usposabiało do pobożności i znajdowało się między ludnością wierną i pobożną" ${ }^{\text {"73 }}$. Przepisy wymagały też, aby eremy

oddalone były co najmniej o dwa kilometry od wielkich miast i osiedli, a to dla ochrony przed hałasem światowym. (...) Jeśli tylko to możliwe erem powinien być usytuowany wśród lasów, które mają być przez pustelników utrzymywane, powiększane i ze stosowną przezornością zagęszczane ${ }^{74}$.

Przepisy te zostały wiernie zrealizowane przy obiorze miejsca na zboczu góry Bielan przez przybyłych w 1602 roku wizytatorów kamedulskich.

Erem na Bielanach znajduje się na wysokości $326 \mathrm{~m}$ npm i zajmuje 11 ha przestrzeni, ogrodzonej murem kamiennym. Jego usytuowaniem zachwycał się na przełomie XIX i XX wieku Walery Eljasz Radzikowski. W swym przewodniku napisał:

Położenie tej pustelni jest prawdziwie romantyczne; widok na piękna, a daleko rozciągającą się okolicę z Wisłą z zamkami i kościołami po górach z łańcuchem Beskidów i ubielonych śniegiem Tatr jest czarujący. Szum wiatru, śpiew ptactwa i odgłosy burzy gdzieś przeciagającej się, są jedynymi tonami, co przerywają ciszę eremu bielańskiego ${ }^{75}$.

Podobne położenie zajmował też erem karmelitów bosych w Czernej na szlaku „Orlich Gniazd”. Usytuowany został w narożu wsi Czerna na stoku góry liczącej $430 \mathrm{~m}$ npm, będącej dawniej własnością Jana Tęczyńskiego, brata fundatorki klasztoru Agnieszki Firlejowej. Wielka klauzura obejmowała teren ten liczący ok. 80,56 ha opasany był murem kamiennym o wys. $2,5 \mathrm{~m}$. i długości $4180 \mathrm{~m}$.

${ }^{72}$ Zob. Widok klasztoru z poł. XVII w., kwasoryt Jerzego Forstera.

${ }^{73}$ Reguta św. Benedykta i Konstytucje Zgromadzenia Kamedutów Pustelników Góry Koronnej, rozdz. XIV, nr 2, s. 378-379.

${ }_{74}$ Konstytucje Kongregacji Pustelników Kamedułów Góry Koronnej, Kraków-Bielany 1991, s. 61 .

${ }^{75}$ W. E. R a d z i k o w s k i, Kraków dawny i dzisiejszy, Kraków 1902, s. 183-184. 
Należal do najobszerniejszych eremów w Europie ${ }^{76}$. Teren ten urzekał pięknym przyrody. Dzikie skały poprzecinane głębokimi jarami z bogatą flora tworzyły odpowiedni klimat do kontemplacji. Na stokach wzniesień oddzielonych dolinkami zaplanowano 12 eremitarzy. Cztery $\mathrm{z}$ nich $\mathrm{w}$ pobliżu klasztoru wzniesiono z kamienia w latach 1635-1637 pod wezwaniem św. Agnieszki ${ }^{77}$, św. Jana Chrzciciela $^{78}$, Wniebowzięcia Najśw. Maryi Panny nad klasztorem i św. Abraha$\mathrm{ma}^{79}$. Po tych trzech ostatnich pustelniach pozostały do naszych czasów ślady ruin i zawalonych piwnic. Do roku 1695 przy kaplicy św. Abrahama była furta klasztorna wraz z zabudowaniami dla gości. W kaplicy tej odprawiano nabożeństwa dla wiernych z Czernej i okolicy.

Wzgórze klasztorne z przeciwległym wzgórzem siedleckim łączył most pustelniczy zw. od końca XIX wieku „diabelskim”, zbudowany w latach 1671-1695 z kamienia i cegły o 13 przęsłach arkadowych. Mial $120 \mathrm{~m}$. długości i 9,5 m. szerokości. Wysokość łuku środkowego ponad lustro wody wynosiła $18 \mathrm{~m}$. Z boku zabezpieczały przechodniów kamienne balustrady. U jego wylotu od strony klasztoru stały potężne rzeźby proroków: Eliasza i Elizeusza. Za mostem urządzono furtę klasztorną z kaplicą dla wiernych i służby klasztornej oraz pralnię i zaplecze gospodarskie. Przed mostem były dwa stawy rybne, a bliżej wsi Paczółtowic źródło św. Eliasza ocembrowane w kształcie wielkiego serca z kapliczką na cześć św. Proroka. Oprócz eremitarzy za rzeczką Eliaszówka były dwie groty wykute w skale: św. Hilariona lub św. M. Magdaleny, a bliżej klasztoru św. Onufrego, która w XVIII w. zwana też była grotą św. Tekli. Groty te zachowały się do obecnych czasów. Od folwarku w Siedlcu prowadziła główna droga do klasztoru przez bramę eremu, most i obecny ogród oraz cmentarz zakonny ${ }^{80}$. Dotychczas w murze cmentarnym od strony ogrodu jest widoczny arkadowy łuk z kluczem kamiennym $\mathrm{z}$ dawnej przejazdowej bramy.

Erem bielański i czerneński usytuowane są na górach. Ma to głęboką symbolikę religijną. Szczyty górskie $z$ powodu ich ukierunkowania w stronę nieba, uważano za miejsca zamieszkania Boga, którego majestat ukrywa się za obłoka$\mathrm{mi}^{81}$. W Starym Testamencie Mojżesz u stóp góry Horeb rozmawiał z Bogiem w ognistym krzewie (Wj 3, 1-5), a potem na górze Synaj (Wj 19, 18-20), a prorok Eliasz na Górze Karmel (1 Krl 18, 41-46). W Nowym Testamencie Chrystus na górze głosił kazanie programowe (Mt 5, 1-12), na górze dokonał wyboru aposto-

${ }^{76}$ Por. B. Z i m m e r ma n OCD, Les saints deserts des Carmes Dechausses, Paris 1927 ; J. W i e ckowska, Z. M y c z kowski, Erem w Czernej - wybitny przyklad dawnej myśli urbanistycznej, [w:] Teka Komisji Urbanistyki i Architektury, t. XVI (1982), s. 163-170.

${ }^{77}$ Patronki fundatorki Agnieszki Firlejowej. Według tradycji miała w niej odprawiać swoje ćwiczenia duchowe. Odbudowana została $\mathrm{z}$ ruin w latach 1966-1969 według projektu arch. Stefana Świszczowskiego, na upamiętnienie millennium chrztu Polski.

${ }^{78} \mathrm{Na} u$ upamiętnienie Jana Tęczyńskiego, wojew. krakowskiego, brata fundatorki klasztoru.

${ }^{79}$ Obecnie na tym miejscu stoi kaplica św. Anny, przy al. św. Józefa.

${ }^{80}$ B. J. W a n a t OCD, Zakon Karmelitów Bosych w Polsce..., s. 301-346; Tenże, Maryjne sanktuarium karmelitów bosych w Czernej. Przewodnik, Kraków 1992, s. 125-128; R omuald od św. El i a z a OCD, Monografia klasztoru oo. karmelitów bosych w Czernej, Bytom 1914.

${ }^{81}$ M. Lurker, Stownik obrazów i symboli biblijnych, Poznań 1989, s. 62. 
łów (Mk 3, 13), na górze Tabor nastapiło Przemienienie Pańskie (Mt 17, 1-8), góra Oliwna była miejscem Jego modlitwy i pojmania (Lk 22, 39-46). Na górze Kalwarii nastapiło Jego Ukrzyżowanie i odkupienia całej ludzkości, na górze Oliwnej Chrystus wstapił do nieba. Położenie na górach klasztorów i eremów zawierało głęboką symbolikę, pomagało pustelnikom w kontemplacji Bożego Oblicza i stanowiło najodpowiedniejszą oprawę wartości ideowych pustelniczego życia.

\section{Summary}

The author shows the similarity of an ideological, artistic, and principle spectrum of an isolated Camaldolese monastery in Bielany, Krakow with an isolated Discalced Carmelites monastery in Czerna in XVII and XVIII centuries. In 2005 passed 400 years from the arrival of the Camaldolites in Bielany in Krakow and also of the Discalced Carmelites on the grounds of Poland. A founder of the isolated Camaldolese monastery in Bielany was Nicholas Wolski (1549-1630), the court-marshal of the king Sigmund III Waza. Pope Clement VIII brought Camaldolese hermits to Krakow and built them a monastery. In 1604, this Pope sent Discalced Carmelite monks with the diplomatic and evangelical mission to Persia who on their way had to stop for a longer time in Krakow. Their stay, in 1605, bore a fruit with a first foundation of the isolated monastery in Krakow. Agnes from Tęczyński Firlej, voivode of Krakow, was a founder of the isolated Discalced Carmelites monastery in Czerna, near Krzeszowice (1578-1644). She covered monastery construction expenses and all interior decorations. To support the hermits she gave them three hamlets: Siedlec, Paczóltowice with Debnik and Zbik. The founders of these monasteries, in compliance with their will, were buried at the entrance of the church crypts so that entering people could pass over their graves. The lifestyle and religious exercises of the hermits in both monasteries were similar. Eremites through their constant prayer and atonement were imploring God's mercy for the whole Motherland. 


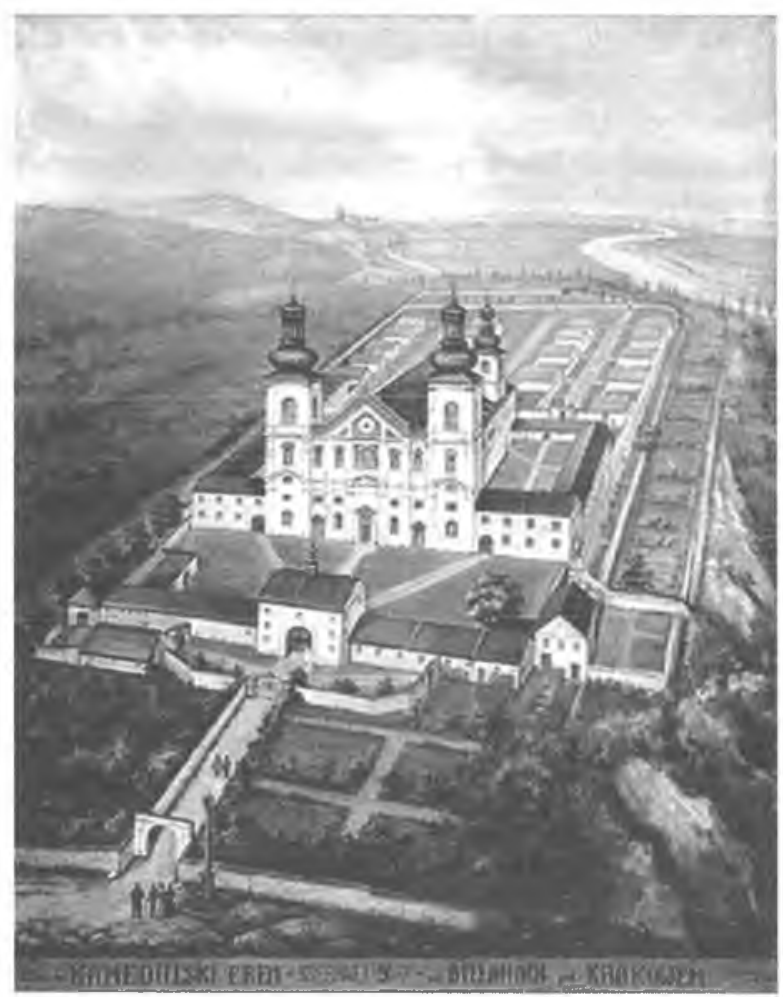

1. Kamedulski Erem Srebrnej Góry na Bielanach w Krakowie. Repr. obrazu olejnego (XVI wiek)

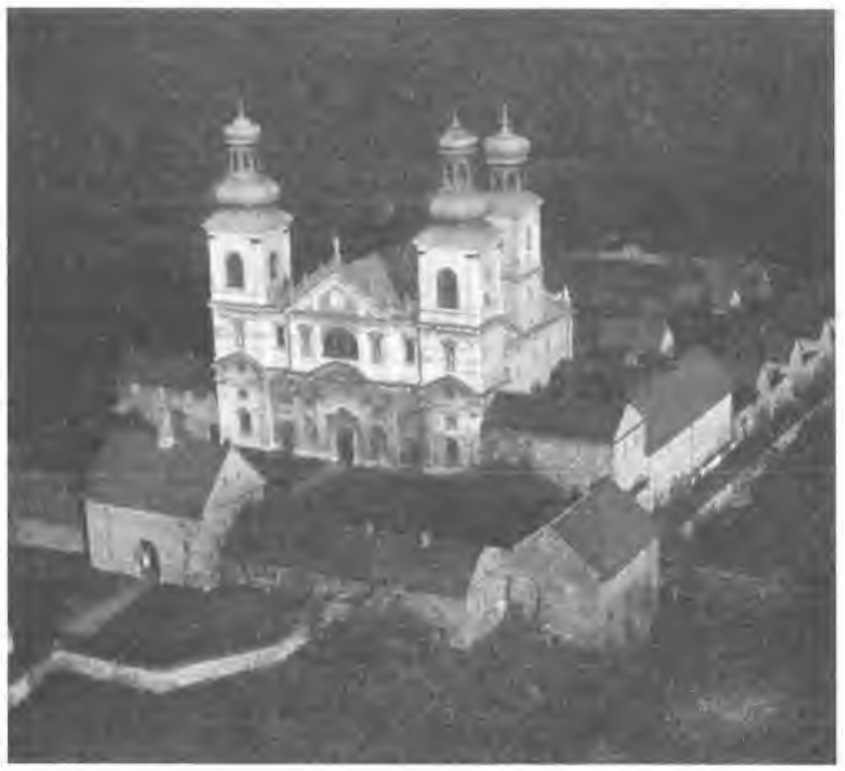

2. Kraków Bielany. Widok od strony południowo-zachodniej 


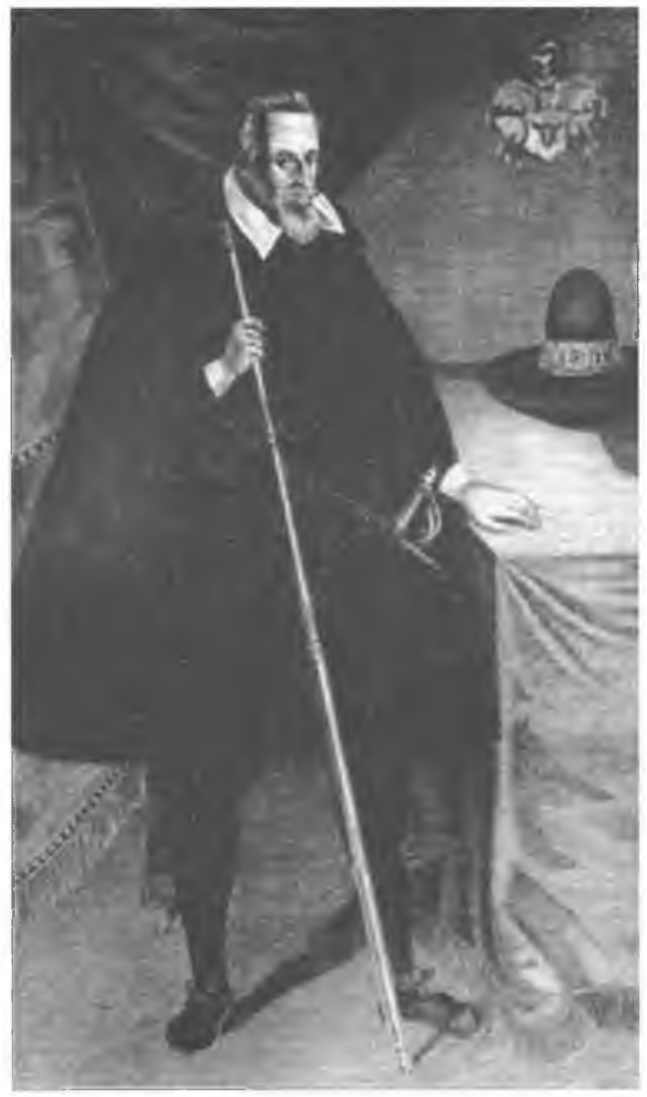

3. Portret fundatora Eremu na Bielanach Mikołaja Wolskiego. Repr. obrazu ze zbiorów klasztornych 


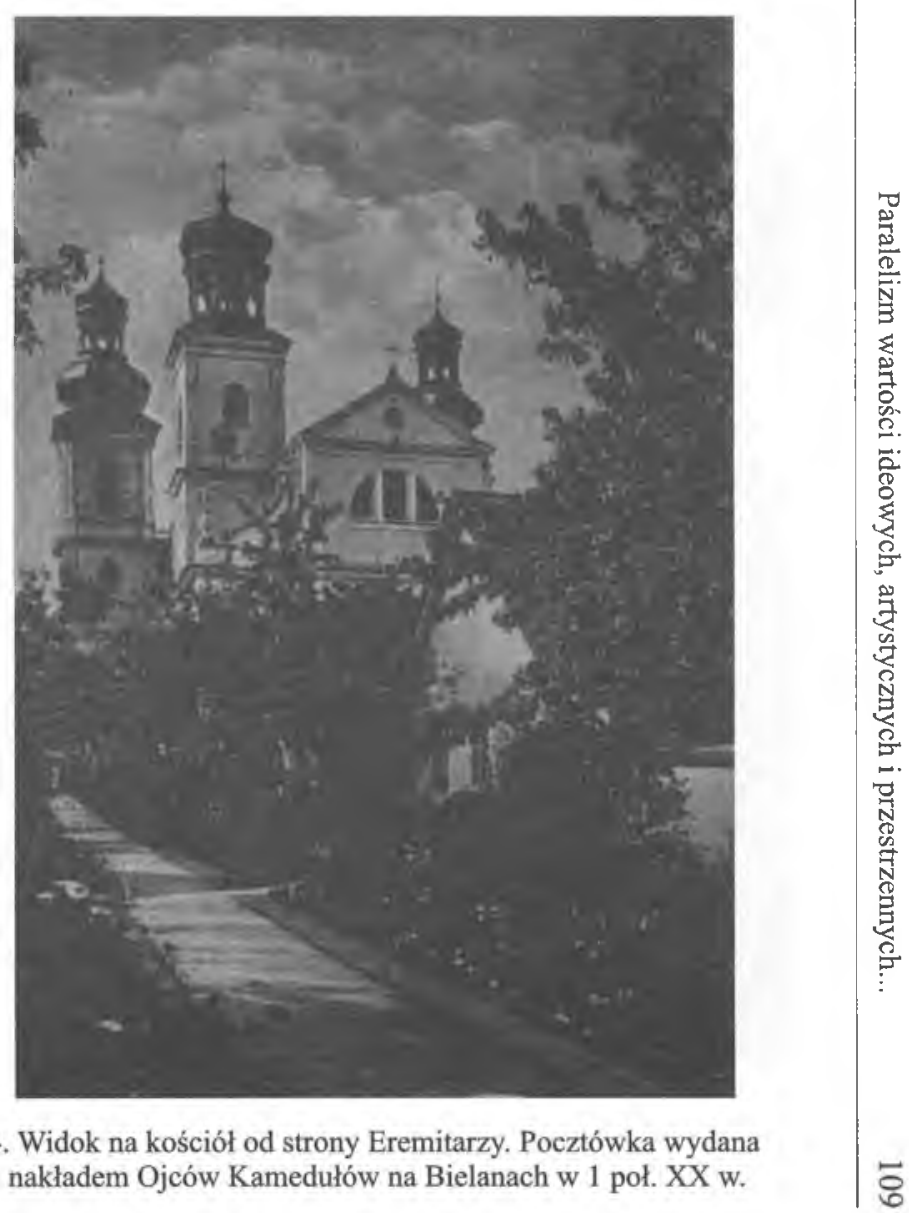




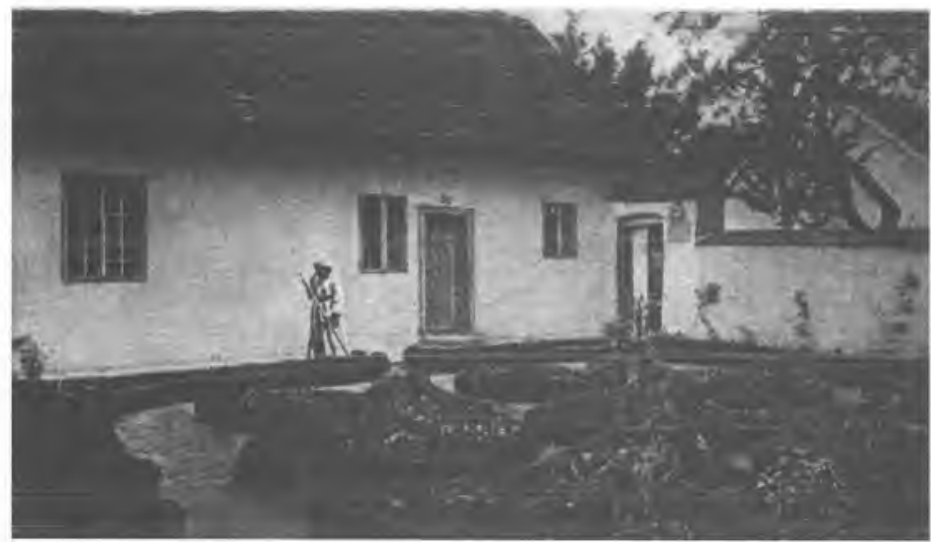

5. Eremitarz z ogródkiem pustelnika. Pocztówka wydana nakładem Ojców Kamedułów na Bielanach w 1 poł. XX w.

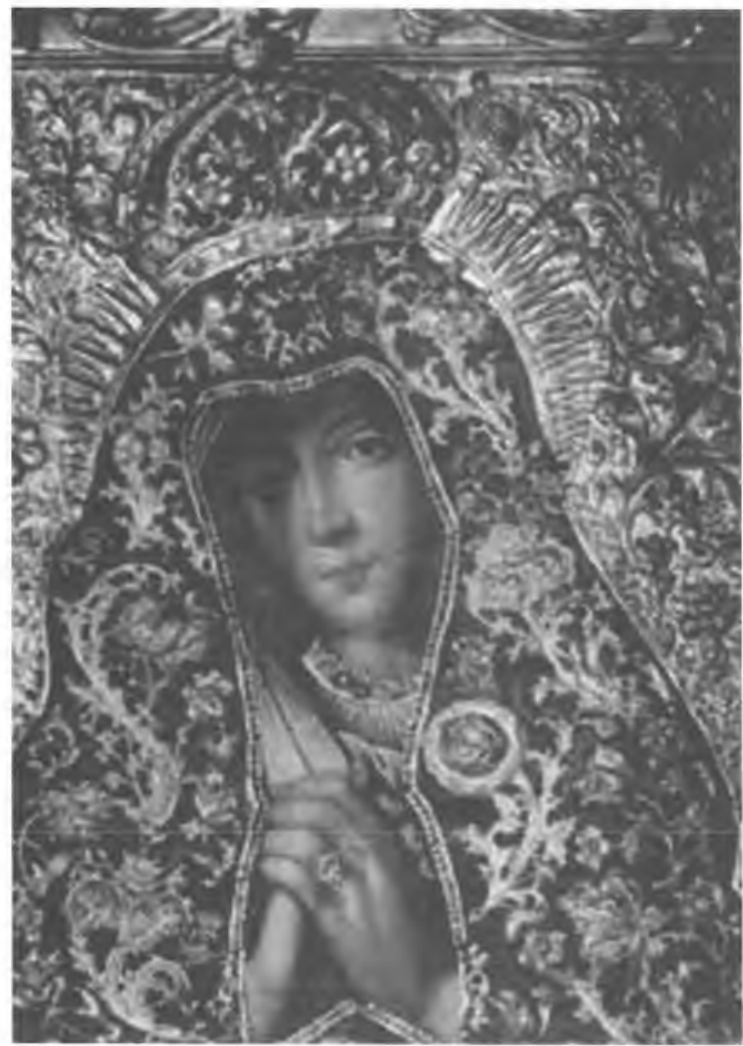

6. Kamedulska Pani. Repr. obrazu Królowej Pustelników w świątyni Eremu w Krakowie na Bielanach (mal. O. Wenanty Kameduła XVII w.) 


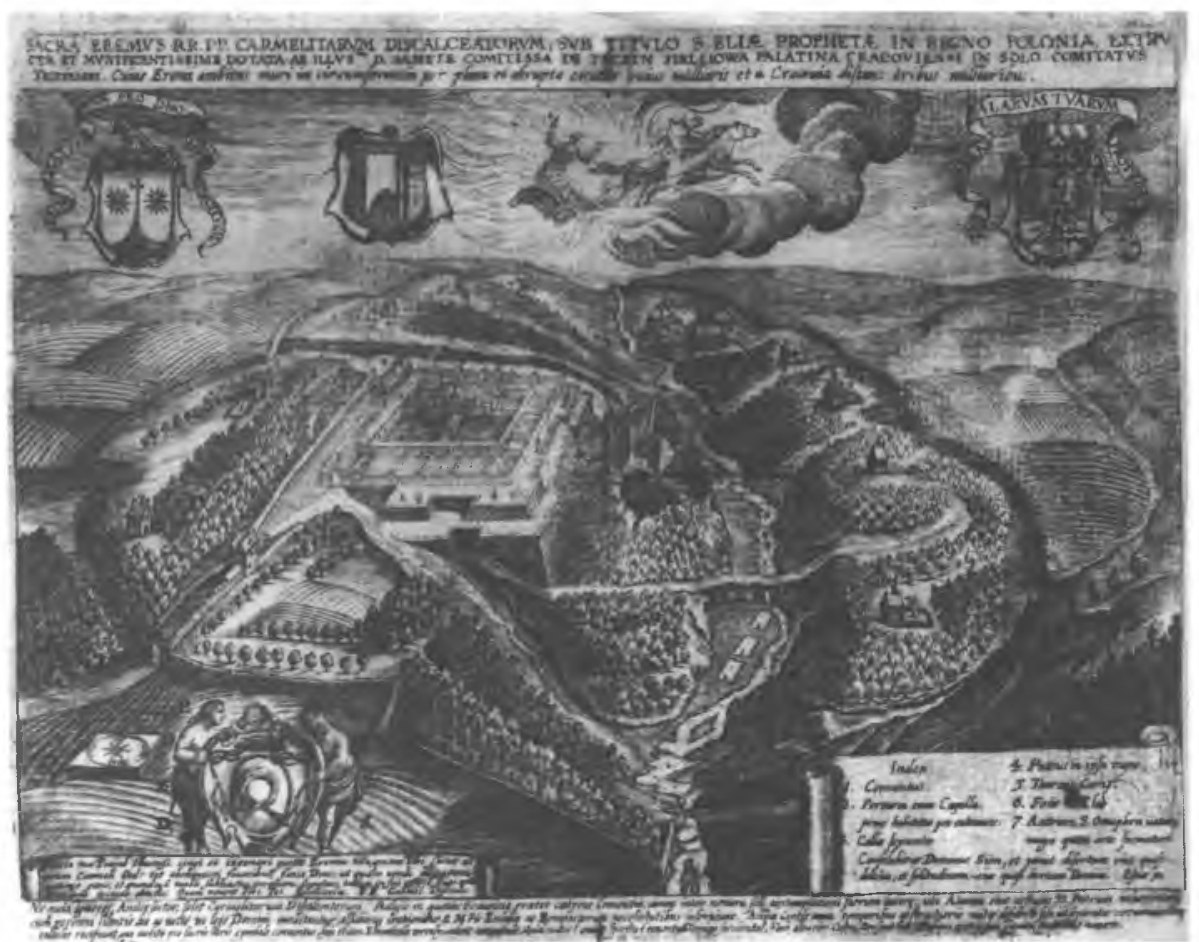

7. Czerna. Ogólny widok eremu św. Eliasza Karmelitów Bosych. Miedzioryt z poł. XVII w. APKB w Czernej

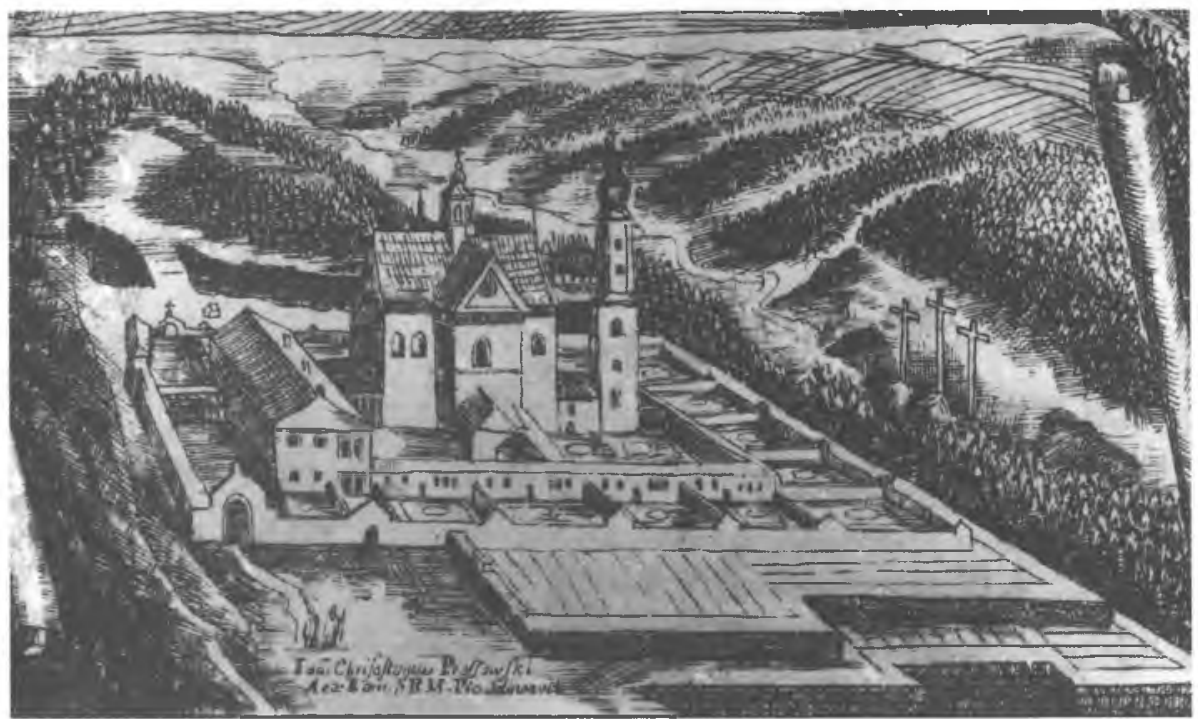

8. Widok na klasztor. Fragment kwasorytu Jerzego Forstera. APKB w Czernej 


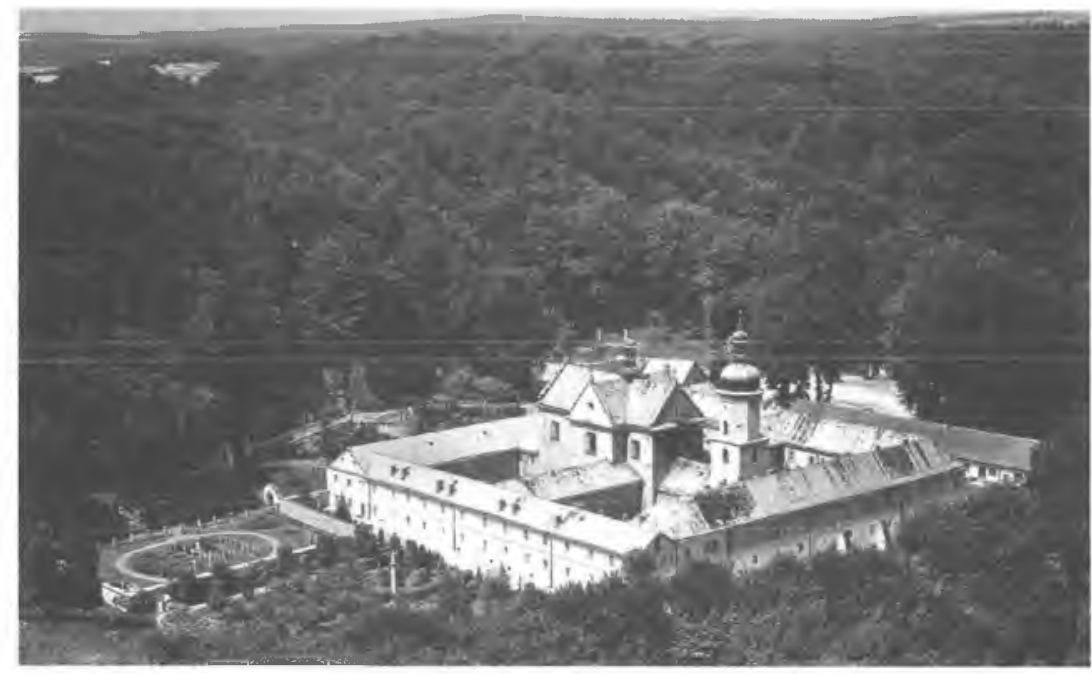

9. Czerna widok klasztoru z lotu ptaka

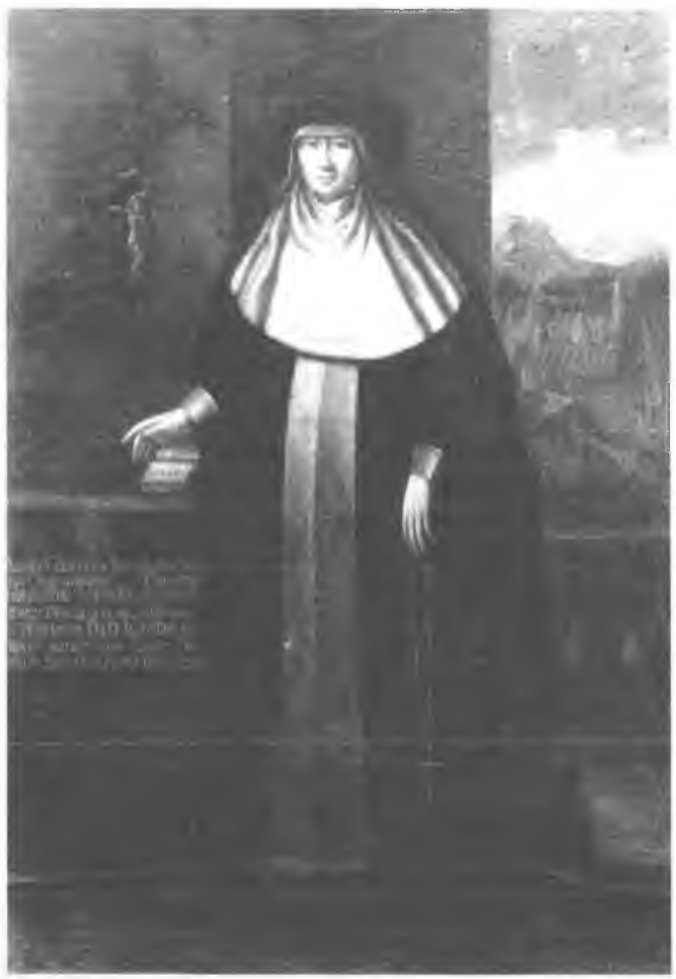

10. Portret Agnieszki Firlejowej z Tęczyńskich fundatorki Eremu w Czernej 


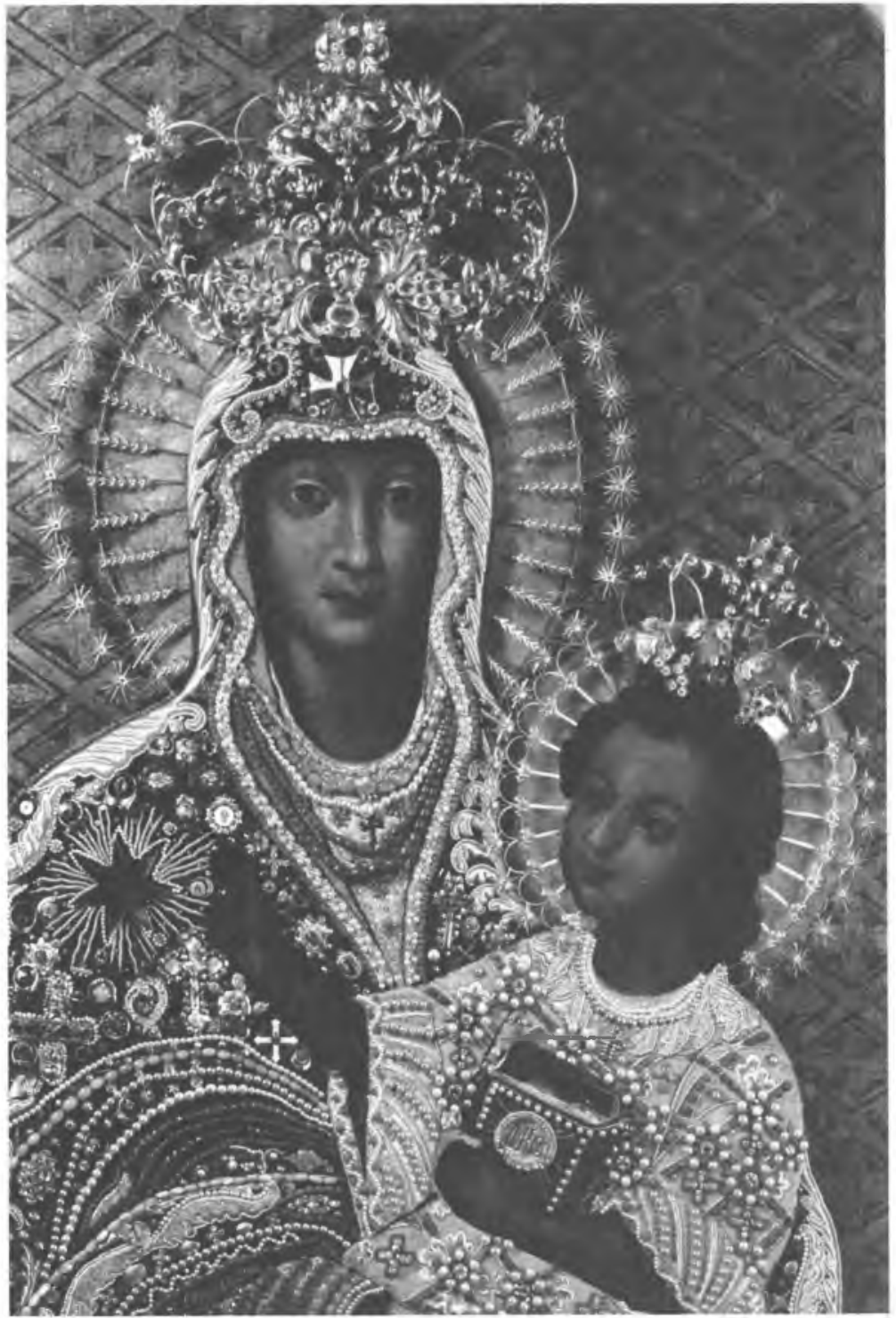

11. Czerna. Fragment łaskami słynącego obrazu Matki Bożej Szkaplerznej przyozdobionego suknią haftowaną $\mathrm{z}$ koralami 


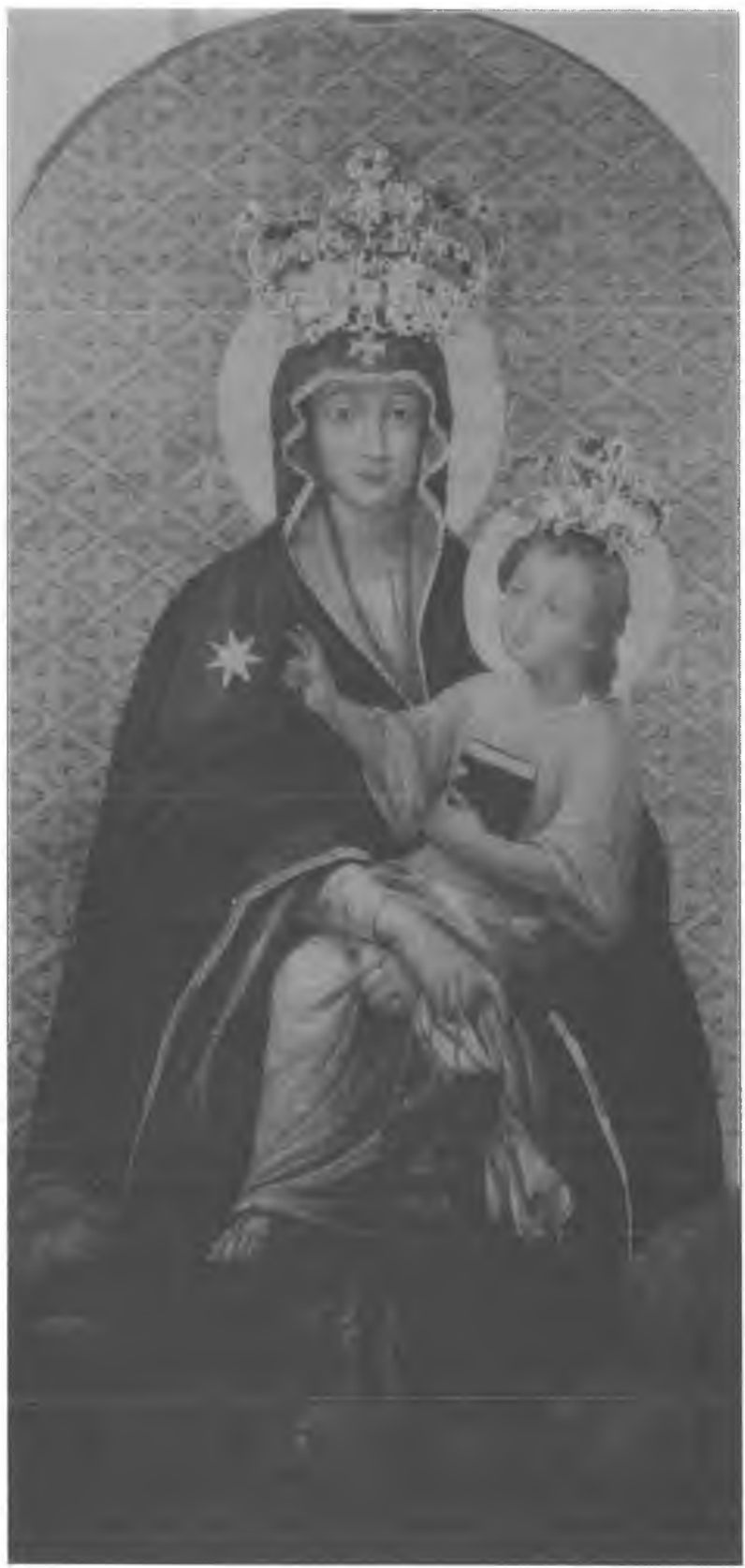

12. Czerna. Laskami słynący obraz Matki Bożej Szkaplerznej z połowy XVIII w., malowany na blasze miedzianej 


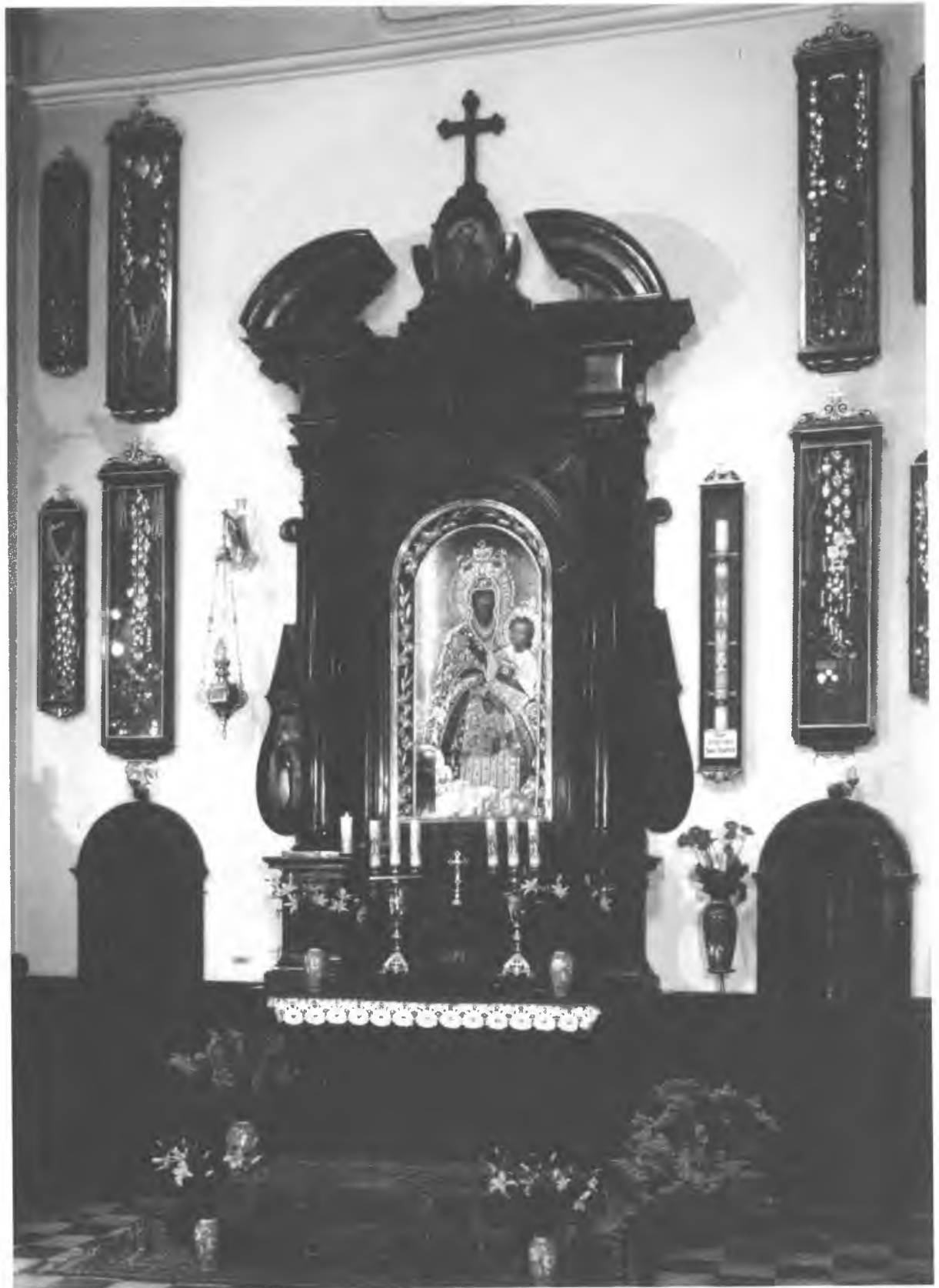

13. Czerna. Marmurowy ołtarz Matki Bożej Szkaplerznej 


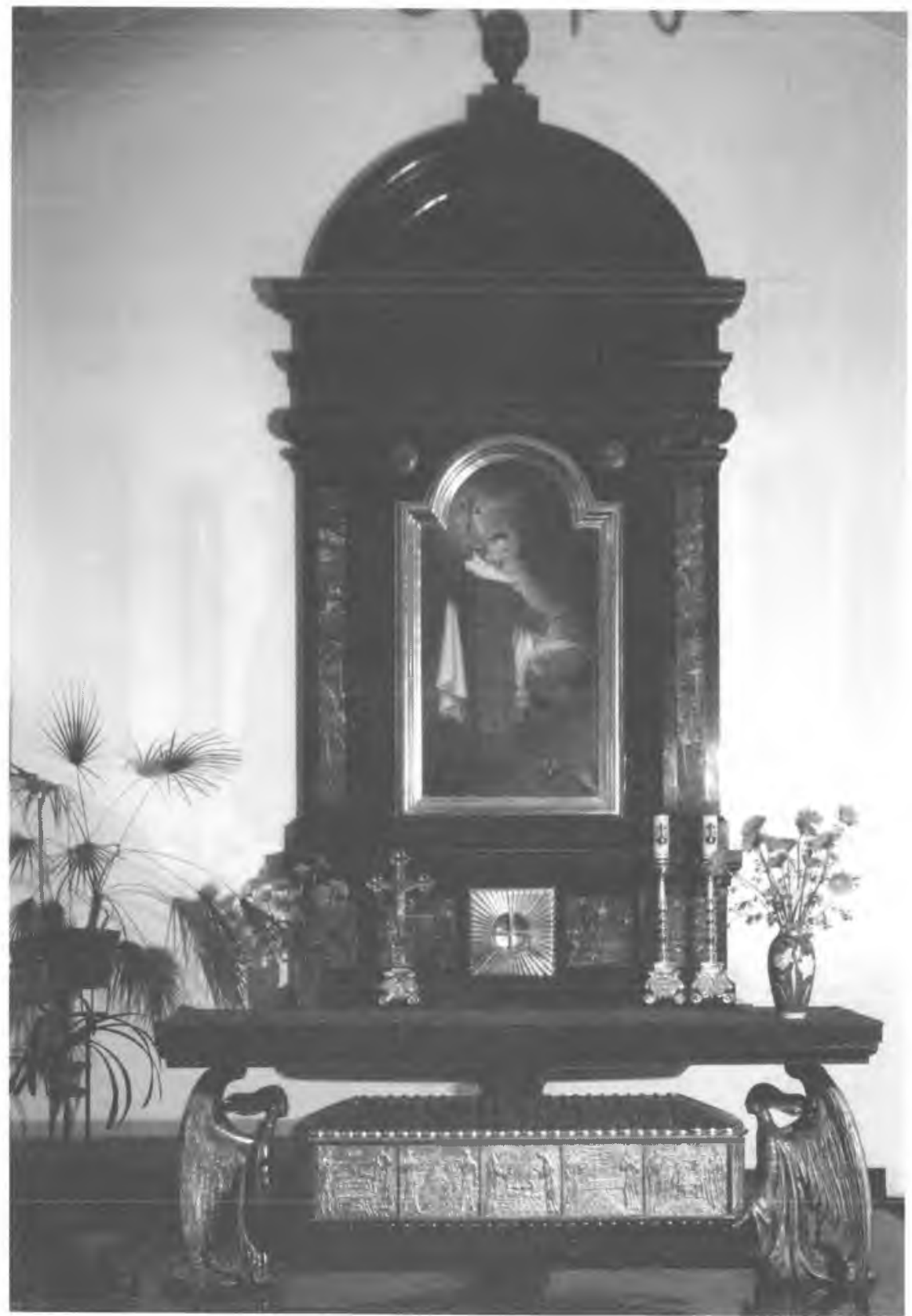

13. Czerna. Ołtarz z sarkofagiem św. Rafała Kalinowskiego 